\title{
Dingchuan tang essential oil inhibits the production of inflammatory mediators via suppressing the IRAK/NF-KB, IRAK/AP-I, and TBKI/IRF3 pathways in lipopolysaccharide- stimulated RAW264.7 cells
}

This article was published in the following Dove Press journal: Drug Design, Development and Therapy

\section{Yi Zhang ${ }^{1,2, *}$ \\ Hui Guo',* \\ Brian Chi-Yan Cheng' \\ Tao Su' \\ Xiu-Qiong Fu' \\ Ting $\mathrm{Li}^{\prime}$ \\ Pei-Li Zhu' \\ Kai-Wing Tse' \\ Si-Yuan $\operatorname{Pan}^{3}$ \\ Zhi-Ling Yu ${ }^{1,3,4}$ \\ 'Centre for Cancer and Inflammation Research, School of Chinese Medicine, Hong Kong Baptist \\ University, Kowloon Tong, Hong Kong; ${ }^{2}$ Department of Pharmacology, Beijing University of Chinese Medicine, Beijing, People's Republic of China; ${ }^{3}$ Research and Development Centre for Natural Health Products, HKBU Shenzhen Research Institute and Continuing Education, Shenzhen, People's Republic of China; ${ }^{4}$ Consun Chinese Medicines Research Centre for Renal Diseases, Hong Kong Baptist University, Hong Kong, People's Republic of China \\ *These authors contributed equally to this work}

Correspondence: Zhi-Ling Yu Centre for Cancer and Inflammation Research, School of Chinese Medicine, Hong Kong Baptist University, 7 Baptist University Road, Kowloon Tong,

Kowloon, Hong Kong

Tel +85234 II 2465

Fax+852 34 I I 246 I

Email zlyu@hkbu.edu.hk
Background: Dingchuan tang (asthma-relieving decoction), a formula of nine herbs, has been used for treating respiratory inflammatory diseases for $>400$ years in the People's Republic of China. However, the mechanisms underlying the anti-inflammatory action of dingchuan tang is not fully understood. This study aims to investigate the effects of Dingchuan tang essential oil (DCEO) on inflammatory mediators and the underlying mechanism of action.

Materials and methods: DCEO was extracted by steam distillation. Lipopolysaccharide (LPS)-stimulated RAW264.7 macrophages were used as the cell model. Production of nitric oxide (NO) was determined by the Griess test. Protein secretion and mRNA levels of inflammatory mediators were measured by the enzyme-linked immunosorbent assay (ELISA) and quantitative real-time polymerase chain reaction (qRT-PCR), respectively. Protein levels were examined by Western blot. Nuclear localization of nuclear factor-kappa B (NF- $\kappa$ B) was detected using immunofluorescence analyses.

Results: DCEO significantly reduced LPS-triggered production of NO and prostaglandin E2 (PGE2) and decreased protein and mRNA levels of inducible nitric oxide synthase (iNOS) and cyclooxygenase-2 (COX-2). LPS induced upregulation of protein and mRNA levels of cytokines (interleukin-1 $\beta$ [IL-1 $\beta]$, interleukin-6 [IL-6], tumor necrosis factor- $\alpha$ [TNF- $\alpha]$ ), and chemokines (monocyte chemoattractant protein-1 [MCP-1], chemokine [C-C motif] ligand 5 [CCL-5], and macrophage inflammatory protein [MIP]-1 $\alpha$ ) were suppressed by DCEO treatment. Phosphorylation and nuclear protein levels of transcription factors (activator protein-1 [AP-1], NF- $\kappa$ B, interferon regulatory factor 3 [IRF3]) were decreased by DCEO. Protein levels

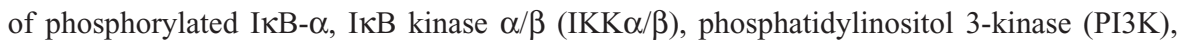
protein kinase B (Akt), TGF $\beta$-activated kinase 1 (TAK1), TANK-binding kinase 1 (TBK1), extracellular signal-regulated kinase (ERK), p38 mitogen-activated protein kinase (p38), and c-Jun N-terminal kinase (JNK) were lowered by DCEO. Moreover, degradation of interleukin-1 receptor-associated kinase 1 (IRAK1) and IRAK4 induced by LPS was inhibited by DCEO treatment.

Conclusion: Suppression of the interleukin-1 receptor-associated kinase (IRAK)/NF- $\kappa B$, IRAK/AP-1 and TBK1/IRF3 pathways was associated with the inhibitory effects of DCEO on inflammatory mediators in LPS-stimulated RAW264.7 macrophages. This study provides a pharmacological justification for the use of dingchuan tang in managing inflammatory disorders.

Keywords: traditional Chinese medicine, respiratory diseases, anti-inflammation, molecular pathways 


\section{Introduction}

Inflammation is a defense mechanism that occurs as a result of exposure of tissues and organs to harmful stimuli such as microbial pathogens, irritants, or toxic cellular components. ${ }^{1}$ Chronic inflammation may induce various diseases, including asthma, rheumatoid arthritis, multiple sclerosis, inflammatory bowel disease, and psoriasis. ${ }^{2}$ These diseases impose a considerable economic burden on the society and shorten the average life expectancy of patients. ${ }^{3}$ Macrophages release inflammatory mediators in response to harmful stimuli, playing a pivotal role in the pathophysiology of inflammatory diseases. ${ }^{4}$ Lipopolysaccharide (LPS), the major structural component of the outer membrane of Gram-negative bacteria, is a potent activator of macrophages. ${ }^{5}$ Toll-like receptor 4 (TLR4) and its downstream signaling pathways involving interleukin-1 receptor-associated kinase (IRAK)/ nuclear factor-kappa B (NF-אB), IRAK/activator protein-1 (AP-1) and TRIF/interferon regulatory factor 3 (IRF3) are activated in LPS-exposed macrophages, ${ }^{6}$ leading to the production of inflammatory mediators (eg, nitric oxide [NO], interleukin-6 [IL-6], tumor necrosis factor [TNF- $\alpha$ ], and interleukin-1 $\beta[\mathrm{IL}-1 \beta]$ ) regulated by these pathways. ${ }^{7,8}$ These inflammatory mediators will further activate macrophages, neutrophils, and lymphocytes, initiating cellular injury and tissue damage..$^{9,10}$

Complementary and alternative medicines are commonly used to treat chronic inflammatory diseases, including respiratory inflammatory conditions. ${ }^{11}$ Dingchuan tang (asthma-relieving decoction) is a traditional Chinese medicine formula, consisting of Herba Ephedrae, Semen Ginkgo, Flos Farfarae, Rhizoma Pinellia, Semen armeniacae amarum, Fructus Perilla, Cortex Mori, Radix Scutellariae, and Radix et Rhizoma Glycyrrhizae at the ratio of $3: 3: 3: 3: 3: 2: 2: 2: 1{ }^{12}$ This formula has been used for treating respiratory inflammatory diseases for centuries in the People's Republic of China. ${ }^{13,14}$ It was originally documented in "She Sheng Zhong Miao Fang" (Effective Formulas for Health Conservation, issued in 1550) as a remedy for asthma. ${ }^{15}$ In patients with asthma, this formula can improve respiratory function and dissipate phlegm. ${ }^{16}$ Pharmacological studies have shown that water extract of dingchuan tang exhibited a strong anti-inflammatory effect in Ovalbumin-induced asthmatic animals. ${ }^{17}$ The mechanism underlying this anti-inflammatory effect may be the inhibition of IKB degradation. ${ }^{18}$

Essential oil isolated from herbal medicines contains various bioactive compounds and possesses anti-inflammatory properties. ${ }^{19-21}$ However, there is no study evaluating the bioactivities of the essential oil isolated from dingchuan tang even though it has been reported that the main volatile compounds in Herba Ephedrae (eg, $\alpha$-terpineol) and Flos Farfarae (eg, oleic acid) have strong anti-inflammatory activities via suppressing the TLR4 signaling pathways. ${ }^{22,23}$ Macrophages play an important role in inflammatory diseases through secretion of a series of inflammatory mediators. ${ }^{4}$ RAW264.7 macrophage line is the most commonly used cell model in inflammation research. Thus, we used RAW264.7 cells to examine the effect of dingchuan tang essential oil (DCEO) on the production of inflammatory mediators and explored the underlying mechanisms.

\section{Materials and methods Herbal preparation}

All the herbs, including Semen Ginkgo (the dried seed of Ginkgo biloba L.), Herba Ephedrae (the dried herbaceous stem of Ephedra sinica Stapf.), Flos Farfarae (the dried flower bud of Tussilago farfara L.), Rhizoma Pinellia (the dried tuber of Pinellia ternata T[hunb.] Breit), Semen armeniacae amarum (the dried seed of Prunus armeniaca L), Fructus Perilla (the dried seed of Perilla frutescens (L.) Britt), Cortex Mori (the dried root bark of Morus alba L.), Radix Scutellariae (the dried root of Scutellaria baicalensis Georgi), and Radix et Rhizoma Glycyrrhizae (the dried root and rhizome Glycyrrhiza uralensis Fisch.), were purchased from the Mr \& Mrs Chan Hon Yin Chinese Medicine Specialty Clinic and Good Clinical Practice Centre in the Hong Kong Baptist University. All of them were authenticated by the corresponding author. Voucher specimens of individual herbs have been deposited at the Centre for Cancer and Inflammation Research, School of Chinese Medicine, Hong Kong Baptist University.

DCEO was prepared using the following procedure: air-dried herbs of Dingchuan tang $(1,002 \mathrm{~g})$ were soaked in 10 times of water (weight of herbs/volume of water is $1: 10$ ) overnight and then extracted by conventional steam distillation using the Clevenger-type apparatus for 5 hours. ${ }^{24}$ After drying with sodium sulfate anhydrous, $400 \mu \mathrm{L}$ of DCEO was obtained and then kept at $4^{\circ} \mathrm{C}$ in dark vials until use.

\section{Gas chromatography-mass spectrometry (GC-MS) analysis of DCEO}

DCEO was analyzed using GC-MS (model QP 2010; Shimadzu, Kyoto, Japan). DB-5MS column (30 $\mathrm{m} \times$ $0.25 \mathrm{~mm} \times 0.25 \mu \mathrm{m}$, Agilent J\&W Scientific) was used; the column flow rate was $1 \mathrm{~mL} / \mathrm{min}$, injector temperature was $240^{\circ} \mathrm{C}$, and detector temperature was $230^{\circ} \mathrm{C}$ under operating conditions. Oven temperature program was set as 
follows: temperature was maintained at $60^{\circ} \mathrm{C}$ for $1 \mathrm{~min}$; then consecutively ramped to $140^{\circ} \mathrm{C}$ at $4^{\circ} \mathrm{C} / \mathrm{min}$, from $140^{\circ} \mathrm{C}$ to $200^{\circ} \mathrm{C}$ at $2.5^{\circ} \mathrm{C} / \mathrm{min}$ and from $200^{\circ} \mathrm{C}$ to $280^{\circ} \mathrm{C}$ at $8^{\circ} \mathrm{C} / \mathrm{min}$; and maintained at a constant temperature for $5 \mathrm{~min}$. In all, $1 \mu \mathrm{L}$ ( $2 \mathrm{mg}$ of DCEO in $1 \mathrm{~mL}$ of methanol) was then injected. Identification of the compounds was based on the comparison of their mass spectra with the NIST 147 Library GC-MS system. The relative concentration of each compound in DCEO was quantified based on the peak area integrated by the analysis program.

A total of 27 compounds were characterized in DCEO, representing $82.2 \%$ of the total essential oil (Figure $\mathrm{S} 1$ ). According to the results obtained from GC-MS analysis (Table S1), the main constituents in DCEO were benzaldehyde $(4.37 \%)$, cycloundecene (E) $(2.36 \%)$, $\alpha$-terpineol (2.96\%), $\beta$-bisabolene (4.71\%), dehydro- $\beta$-ionone $(28.43 \%)$, $n$-hexadecanoic acid (9.21\%), and oleic acid (6.20\%).

\section{Reagents}

Bovine serum albumin (BSA), 3-(4,5-dimethylthiazol-2-yl)2,5-diphenyltetrazolium bromide (MTT), LPS (Escherichia coli O55:B5), Griess reagent (modified) and Dimethyl sulfoxide (DMSO) were purchased from Sigma-Aldrich Co. ( $\mathrm{St}$ Louis, MO, USA). Fetal bovine serum (FBS), Dulbecco's Modified Eagle's Medium (DMEM), penicillin, and streptomycin were obtained from HyClone (Logan, UT, USA). RAW264.7 cell line, BALB/c-derived murine macrophage line (ATCC, TIB-71) was purchased from American Type Culture Collection (ATCC; Manassas, VA, USA). IL-1 $\beta$, IL-6, TNF- $\alpha$, monocyte chemoattractant protein-1 (MCP-1), macrophage inflammatory protein (MIP)- $1 \alpha$ and chemokine (C-C motif) ligand 5 (CCL-5) enzyme-linked immunosorbent assay (ELISA) kits were obtained from eBioscience (San Diego, CA, USA). Prostaglandin E2 (PGE2) ELISA kit was obtained from Enzo Life Sciences (Exeter, UK). NF- $\kappa$ B

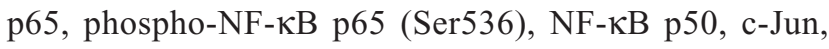
phospho-c-Jun (Ser63), protein kinase B (Akt), phospho-Akt (Ser473), and Pol II (H-224) monoclonal antibodies were obtained from Santa Cruz Biotechnology Inc. (Dallas, TX, USA). Cyclooxygenase-2 (COX-2), inducible nitric oxide synthase (iNOS), IRF3, phospho-IRF3 (Ser396), IкB $\alpha$, phospho-IкB $\alpha$ (Ser32), IкB kinase $\alpha / \beta$ (IKK $\alpha / \beta)$, phosphoIKK $\alpha / \beta$ (Ser176/180), extracellular signal-regulated kinase (ERK), phospho-ERK (Thr202/Tyr204), c-Jun N-terminal kinase (JNK), phospho-JNK (Thr183/Tyr185), p38 mitogen-activated protein kinase (p38), phospho-p38 (Thr180/ Tyr182), phosphoinositide (PI) 3-kinase p85, phospho-PI3 kinase p85 (Tyr458)/p55 (Tyr199), TGF $\beta$-activated kinase 1
(TAK1), phospho-TAK1 (Ser412), interleukin-1 receptorassociated kinase 1 (IRAK1), IRAK4, TANK-binding kinase 1 (TBK1), phospho-TBK1 (Ser172), c-Fos, phospho-c-Fos (Ser32), and goat anti-mouse (\#4408S) conjugated to Alexa Fluor 488 antibodies were obtained from Cell Signaling Technology (Boston, MA, USA).

\section{Cell culture}

RAW264.7 cells were cultured in the DMEM medium containing 5\% heat-inactivated FBS and $1 \%$ antibiotics of penicillin/streptomycin at $37^{\circ} \mathrm{C}$ under $5 \% \mathrm{CO}_{2}$. Before each assay, cells were seeded in plates and allowed to attach for $24 \mathrm{~h}$, and then, the culture medium was replaced with the fresh medium supplemented with DCEO solution or the vehicle. DCEO solution was prepared by dissolving the essential oil in DMSO and freshly diluting to the desired concentration with the culture medium. The final concentration of DMSO was $0.05 \%(\mathrm{v} / \mathrm{v})$.

\section{Cell viability assay}

The effect of DCEO on the viability of RAW264.7 cells was determined using the MTT assay. Briefly, RAW264.7 cells were seeded in 96-well plates at a density of $5 \times 10^{3}$ cells/well. After a $24 \mathrm{~h}$ cultivation, DCEO was added to the cells and incubated for $1 \mathrm{~h}$, and then, the cells were treated with or without LPS (100 ng/mL dissolved in phosphate-buffered saline [PBS]) for $24 \mathrm{~h}$. Next, $10 \mu \mathrm{L}$ of MTT solution $(5 \mathrm{mg} / \mathrm{mL})$ was added to each well and the cells were incubated for $3 \mathrm{~h}$ at $37^{\circ} \mathrm{C}$. Then, $100 \mu \mathrm{L}$ of DMSO was added to dissolve the MTT-formazan crystal. The absorbance at $570 \mathrm{~nm}$ was measured using a microplate spectrophotometer (Bio-Rad Benchmark Plus; Bio-Rad Laboratories Inc., Hercules, CA, USA). Cell viability in the control group (cells were not treated by DCEO or LPS) was set as 100\%. Six replicate wells were used in this experiment.

\section{Determination of $\mathrm{NO}$}

Nitrite $\left(\mathrm{NO}_{2}^{-}\right)$levels, an index of cellular $\mathrm{NO}$ production, in culture supernatants of RAW264.7 cells were determined using a modified Griess reagent as described previously. ${ }^{25}$ Briefly, cells were seeded at $1 \times 10^{6}$ cells $/ \mathrm{mL}$ in 24 -well culture plates. After a $24 \mathrm{~h}$ cultivation, these cells were treated with DCEO at various concentrations for $1 \mathrm{~h}$ and then at the presence or absence of LPS (100 ng/mL) for $24 \mathrm{~h}$. The supernatant was mixed with an equal volume of Griess reagent and incubated at room temperature for $15 \mathrm{~min}$. Absorbance at $540 \mathrm{~nm}$ was measured with a $\mathrm{NaNO}_{2}$ standard curve, 
and nitrite production was determined. Four replicate wells were used in this experiment.

\section{ELISA}

The production of IL-1 $\beta$, IL-6, TNF- $\alpha$, PGE2, MCP-1, MIP-1 $\alpha$, and CCL-5 was determined by ELISA. Briefly, RAW264.7 macrophages were seeded in 24-well culture plates at $1 \times 10^{5}$ cells/well. After a $24 \mathrm{~h}$ cultivation, the cells were treated with DCEO at various concentrations for $1 \mathrm{~h}$ and then supplemented with or without LPS $(100 \mathrm{ng} / \mathrm{mL})$ for $24 \mathrm{~h}$. Cell-free supernatants were collected for determination of cytokine and chemokine concentrations according to the manufacturer's instructions. Four replicate wells were used in this experiment.

\section{RNA extraction and quantitative real-time polymerase chain reaction ( $q R T-P C R$ )}

RAW264.7 cells were seeded in 60-mm-diameter culture dishes $\left(4 \times 10^{5}\right.$ cells $\left./ \mathrm{mL}\right)$ for $24 \mathrm{~h}$ and treated with DCEO at various concentrations. LPS $(100 \mathrm{ng} / \mathrm{mL})$ was added $1 \mathrm{~h}$ after DCEO treatment, and the cells were incubated at $37^{\circ} \mathrm{C}$ for $6 \mathrm{~h}$. Total RNA was extracted using TRIzol reagent (Thermo Fisher Scientific, Waltham, MA, USA) and reverse-transcripted with oligo-dT using the PrimeScript ${ }^{\mathrm{TM}}$ RT reagent Kit (Takara Bio Inc., Shiga, Japan) according to the manufacturer's protocol. qRT-PCR was carried out by monitoring the increase in fluorescence of SYBR Green using the ViiA 7 Real-Time PCR System (Thermo Fisher Scientific). Primers were synthesized by Invitrogen (iNOS primers: forward AGCAACTACTGCT GGTGGTG and reverse TCTTCAGAGTCTGCCCATTG, COX-2 primers: forward CTGGAACATGGACTCACT CAGTTTG and reverse AGGCCTTTGCCACTGCTTGT, IL-6 primers: forward AGTCCGGAGAGGAGACTTCA and reverse ATTTCCACGATTTCCCAGAG, IL-1 $\beta$ primers: forward GAAGAAGAGCCCATCCTCTG and reverse TCATCTCGGAGCCTGTAGTG, TNF- $\alpha$ primers: forward ATGAGAAGTTCCCAAATGGC and reverse CTCCACTTGGTGGTTTGCTA, CCL-5 primers: forward CATATGGCTCGGACACCA and reverse ACACACTTGGCGGTTCCT, MCP-1 primers: forward AATGCTAACGCCACCGAGAG and reverse CCTTGT TCTGCTCCTCATAGTCC, MIP- $1 \alpha$ primers: forward CCCAGCCAGGTGTCATTTTCC and reverse GCATT CAGTTCCAGGTCAGTG, and GAPDH primers: forward GGCCTTCCGTGTTCCTACC and reverse TGCCTGCTT CACCACCTTC). Each sample was amplified in triplicate for quantification. Data were analyzed by relative quantification using the $\Delta \Delta C_{t}$ method and normalized to GAPDH. Three replicate wells were used in this experiment.

\section{Western blot analysis}

Cell lysates were prepared as previously described. ${ }^{26}$ Briefly, RAW264.7 cells were seeded in 60-mm-diameter culture dishes $\left(4 \times 10^{5}\right.$ cells $\left./ \mathrm{mL}\right)$ for $24 \mathrm{~h}$ and treated with DCEO at various concentrations. LPS $(100 \mathrm{ng} / \mathrm{mL})$ was added $1 \mathrm{~h}$ after DCEO pretreatment, and the cells were incubated at $37^{\circ} \mathrm{C}$ for 30 or $60 \mathrm{~min}$. The cells were then washed twice in icecold PBS and lysed with RIPA buffer consisting of $50 \mathrm{mM}$ Tris-HCl, 1\% NP-40, 0.35\% sodium deoxycholate, $150 \mathrm{mM}$ $\mathrm{NaCl}, 1 \mathrm{mM}$ EDTA of $\mathrm{pH} 7.4,1 \mathrm{mM}$ phenylmethylsulfonyl fluoride, $1 \mathrm{mM} \mathrm{NaF}, 1 \mathrm{mM} \mathrm{Na} \mathrm{VO}_{4}, 10 \mu \mathrm{g} / \mathrm{mL}$ aprotinin, $10 \mu \mathrm{g} / \mathrm{mL}$ leupetin, and $10 \mu \mathrm{g} / \mathrm{mL}$ pepstatin A. The supernatant was collected after the cell lysate was centrifuged at $14,000 \times \mathrm{g} / \mathrm{min}$ for $15 \mathrm{~min}$ at $4^{\circ} \mathrm{C}$. The protein concentration was measured using the Bio-Rad Protein Assay Kit (Bio-Rad Laboratories Inc.). Equal amount of protein sample (30 $\mu \mathrm{g})$ was resolved by sodium dodecyl sulfate polyacrylamide gel electrophoresis (SDS-PAGE) sample loading buffer and denatured for $10 \mathrm{~min}$ at $95^{\circ} \mathrm{C}$. Subsequently, the samples were electrophoresed on $12 \%$ SDS-PAGE mini-gel and transferred onto nitrocellulose membrane at $80 \mathrm{~V}$ for $3 \mathrm{~h}$ at $4^{\circ} \mathrm{C}$. Membranes were probed with indicated primary antibodies over night at $4^{\circ} \mathrm{C}$ and were then blotted with respective horseradish peroxidase-conjugated secondary anti-mouse or anti-rabbit antibody. The specific proteins were detected using enhanced chemiluminescence (ECL) detection kit (Thermo Fisher Scientific) following the manufacturer's instruction, and the blots were analyzed using the ImageJ software (National Institutes of Health [NIH], Bethesda, MD, USA).

\section{Extraction of cytoplasmic and nuclear proteins}

The cytoplasmic and nuclear proteins were prepared as previously described. ${ }^{26}$ Briefly, cells were collected for Western blot as described in Western blot analysis section. Cells were washed three times with ice-cold PBS and then suspended in hypotonic buffer for cytosolic extraction. After incubation on ice for $15 \mathrm{~min}, 12 \mu \mathrm{L}$ of $10 \%(\mathrm{v} / \mathrm{v}) \mathrm{NP}-40$ was added to the suspension for another $10 \mathrm{~min}$. The cytoplasmic fraction was prepared by centrifugation for $2 \mathrm{~min}$. The remaining cell pellet generated after initial centrifugation was washed three times with the hypotonic buffer and suspended in high-salt buffer. The suspended cell pellet was incubated for $30 \mathrm{~min}$ on ice and then centrifuged for $10 \mathrm{~min}$ to obtain the nuclear 
fraction. Soluble cell lysates were immunoblotted with the designated antibodies.

\section{Immunofluorescence staining}

RAW264.7 cells were directly cultured on chamber slides (Cat. 177399; Thermo Fisher Scientific) for $24 \mathrm{~h}$ to detect $\mathrm{NF}-\kappa \mathrm{B} / \mathrm{p} 65$ nuclear localization by immunofluorescence assays using a fluorescence microscope. Briefly, after a 60 min stimulation with LPS in the presence or absence of DCEO, cells were fixed with $4 \%$ formaldehyde in PBS for $15 \mathrm{~min}$ at room temperature and permeabilized with $0.25 \%$ Triton-X for $30 \mathrm{~min}$ at $37^{\circ} \mathrm{C}$ and followed by $10 \mathrm{~min}$ at room temperature. After blocking with $3 \%$ bovine serum albumin (BSA) for $2 \mathrm{~h}$, the cells were incubated with the primary antibody anti-NF- $\kappa \mathrm{B} / \mathrm{p} 65$ overnight at $4^{\circ} \mathrm{C}$. After washing with PBS for three times, cells were incubated for $1 \mathrm{~h}$ at room temperature with Alexa Fluor 488-conjugated secondary antibody, the nuclei were stained with DAPI, and fluorescence was visualized using a fluorescence microscope (Leica Microsystems, Wetzlar, Germany).

\section{Statistical analysis}

At least three replicate wells were used per experimental setting. All values were expressed as arithmetic mean \pm standard error of the mean. Data were analyzed by one-way analysis of variance (ANOVA) using SPSS (version 16.0) statistical analysis program, and then, differences among mean were determined using Dunnett's multiple comparison test. Differences were considered as significant at $P<0.05$.

\section{Results \\ DCEO lowered NO and PGE2 production}

The viability of RAW264.7 cells was not significantly altered by a 24-h incubation of up to $50 \mu \mathrm{g} / \mathrm{mL}$ of DCEO in the presence of $100 \mathrm{ng} / \mathrm{mL}$ of LPS (Figure 1A). Concentrations of DCEO of $12.5,25$, and $50 \mu \mathrm{g} / \mathrm{mL}$ were used in subsequent experiments. As shown in Figure $1 \mathrm{~B}$ and $\mathrm{C}$, significant increases in NO and PGE2 resulting from LPS stimulation in RAW264.7 cells were suppressed by DCEO treatment in a dose-dependent manner.

\section{DCEO downregulated protein and mRNA levels of iNOS and COX-2}

As NO and PGE2 syntheses are catalyzed by iNOS and COX-2, respectively, ${ }^{27,28}$ we next examined protein and mRNA levels of iNOS and COX-2 using Western blot and qRT-PCR, respectively. Figure 1D-F showed that treatment with DCEO decreased LPS-triggered upregulation of cellular protein levels of iNOS and COX-2 in a dosedependent manner. Moreover, DCEO treatment significantly decreased the elevated levels of iNOS and COX-2 mRNA induced by LPS in a concentration-dependent manner (Figure $1 \mathrm{G}$ and $\mathrm{H}$ ).

\section{DCEO decreased cytokine and chemokine production and gene expression levels}

Activation of macrophages via TLR4 signaling induces production of critical proinflammatory cytokines (eg, IL-1 $\beta$, IL-6, and TNF- $\alpha$ ) and chemokines (eg, MCP-1, CCL-5, and MIP-1 $\alpha$ ) that are necessary to activate inflammatory responses. ${ }^{29}$ Therefore, these cytokines and chemokines are regarded as targets for inhibiting LPS-induced inflammatory responses. Our ELISA data showed that production of TLR4-mediated cytokines (IL-1 $\beta$, IL-6, and TNF- $\alpha$ ) and chemokines (MCP-1, CCL-5, and MIP-1 $\alpha$ ) was markedly increased upon LPS stimulation, and the increments were concentration-dependently inhibited by DCEO treatment (Figure 2A-F).

We further investigate the effect of DCEO on the gene expression of the corresponding cytokines and chemokines. In line with the ELISA results, stimulation with LPS upregulated mRNA levels of cytokines (IL-1 $\beta$, IL-6, and TNF- $\alpha$ ) and chemokines (MCP-1, CCL-5, and MIP-1 $\alpha$ ) in RAW264.7 macrophages, and the levels of mRNA of IL-1 $\beta$, IL-6, TNF- $\alpha$, MCP-1, CCL-5, and MIP- $1 \alpha$ were significantly lowered by DCEO treatment in a concentration-dependent manner (Figure 3A-F). GAPDH was used as an internal control, which has been validated in our facility and in RAW264.7 cells. ${ }^{30}$

\section{DCEO affected the components of the IRAK/NF-KB, IRAK/AP-I, and TBKI/IRF3 pathways}

The above data showed that DCEO could inhibit proinflammatory cytokines and chemokines regulated by TLR4 signaling. The involvement of TLR4 signaling in the effects of DCEO was further explored in LPS-stimulated RAW264.7 macrophages. TLR4 signaling cascades involve MyD88-dependent and -independent signaling pathways. The MyD88-dependent pathway involves the early phase of NF- $\kappa \mathrm{B}$ and AP-1 activation, which leads to the production of inflammatory cytokines. ${ }^{31}$ As shown in Figures 4B and 5B, the phosphorylations of NF- $\mathrm{KB}$ subunit p65 (ser536) and AP-1 (c-Jun and c-Fos) were obviously elevated after $1 \mathrm{~h}$ 


\section{A}
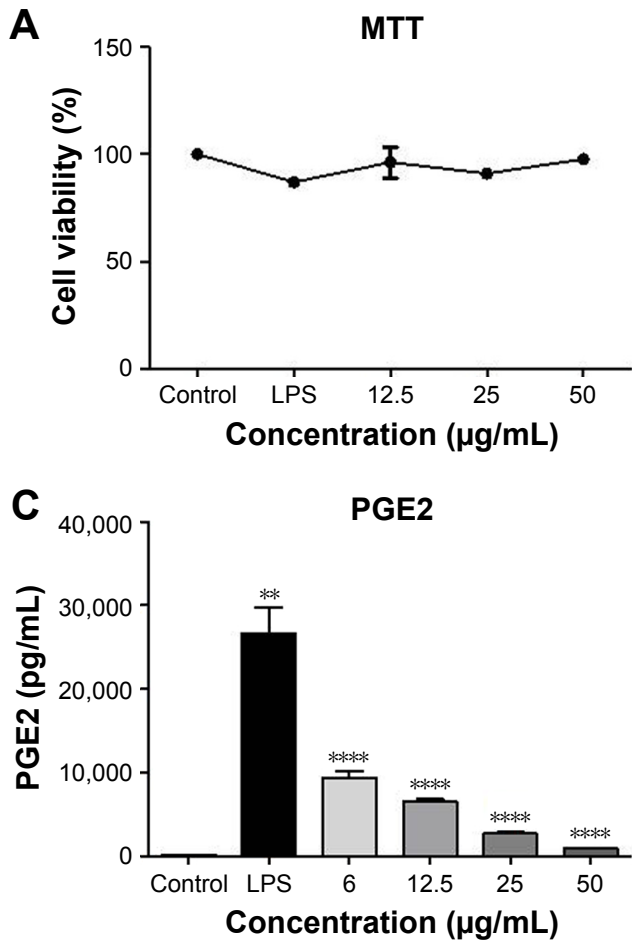

E

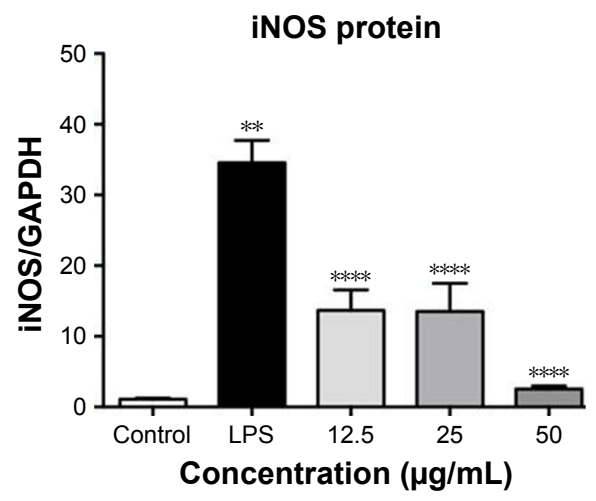

G

iNOS mRNA

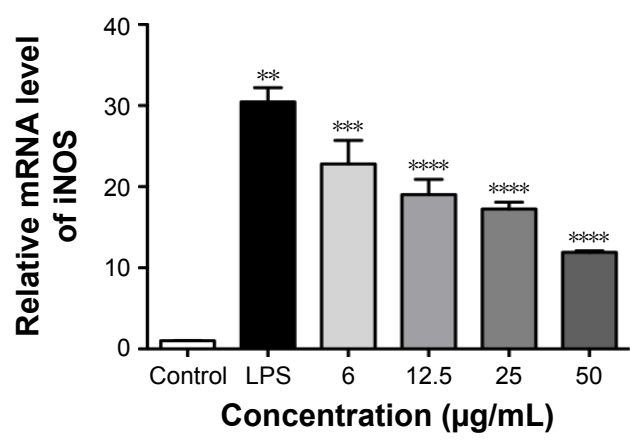

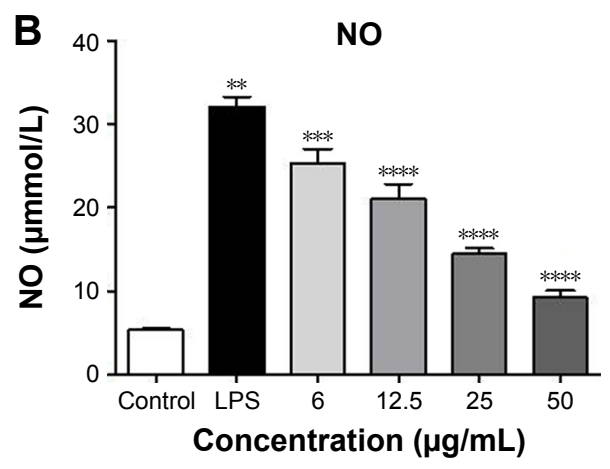

D

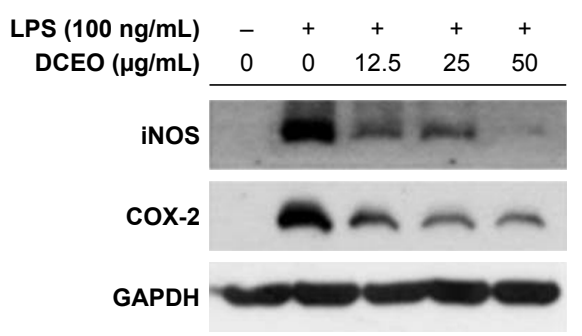

F

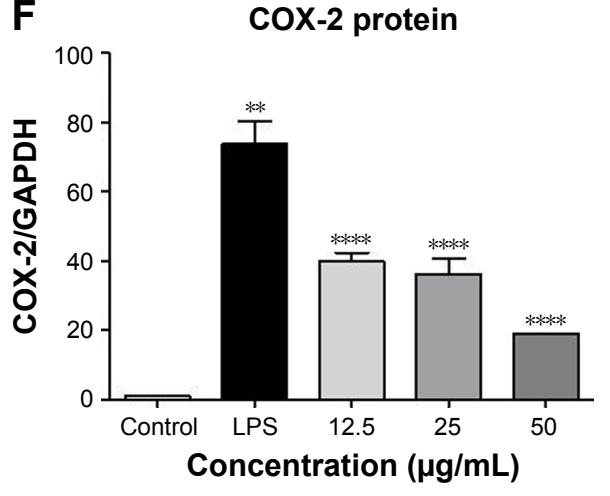

H

COX-2 mRNA

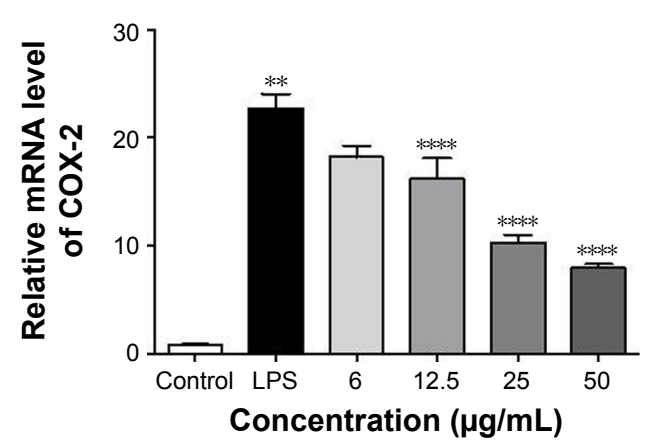

Figure I DCEO inhibited the production of NO and PGE2 and the expression of iNOS and COX-2 in LPS-stimulated RAW264.7 cells.

Notes: Cells were incubated with indicated concentrations of DCEO for $24 \mathrm{~h}$ with or without LPS. Cell viability was determined by the MTT assay. Results were expressed as percentages of respective controls (A). Cells were incubated with indicated concentrations of DCEO for I h and then stimulated with LPS for $24 \mathrm{~h}$. The production of NO was indicated by the level of nitrite formed in the supernatant detected using the Griess reagent. PGE2 production was measured by ELISA (B and C). The protein levels of iNOS and COX-2 were determined by immunoblotting. Representative blots of iNOS and COX-2 are shown (D). Bar graphs show the relative levels of iNOS and COX-2 in RAW264.7 cells (E and F). Cells were incubated with indicated concentrations of DCEO for I $h$ and then stimulated with LPS for $6 \mathrm{~h}$. The mRNA levels of iNOS and COX-2 were determined by qRT-PCR ( $\mathbf{G}$ and $\mathbf{H}$ ). Data presented in bar charts are mean \pm SEM values from three independent experiments. $* * P<0.01$ vs unstimulated cells. $* * * P<0.05$ and $* * * * P<0.01$ vs LPS-stimulated cells determined by Dunnett's multiple comparisons test.

Abbreviations: DCEO, Dingchuan tang essential oil; NO, nitric oxide; PGE2, prostaglandin E2; iNOS, inducible nitric oxide synthase; COX-2, cyclooxygenase-2; LPS, lipopolysaccharide; MTT, 3-(4,5-dimethylthiazol-2-yl)-2,5-diphenylthiazolium bromide; ELISA, enzyme-linked immunosorbent assay; qRT-PCR, quantitative real-time polymerase chain reaction; SEM, standard error of the mean. 


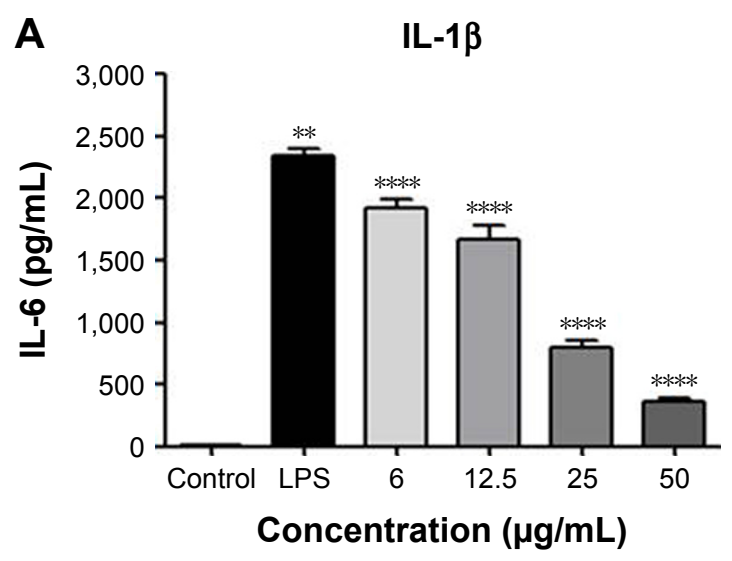

B
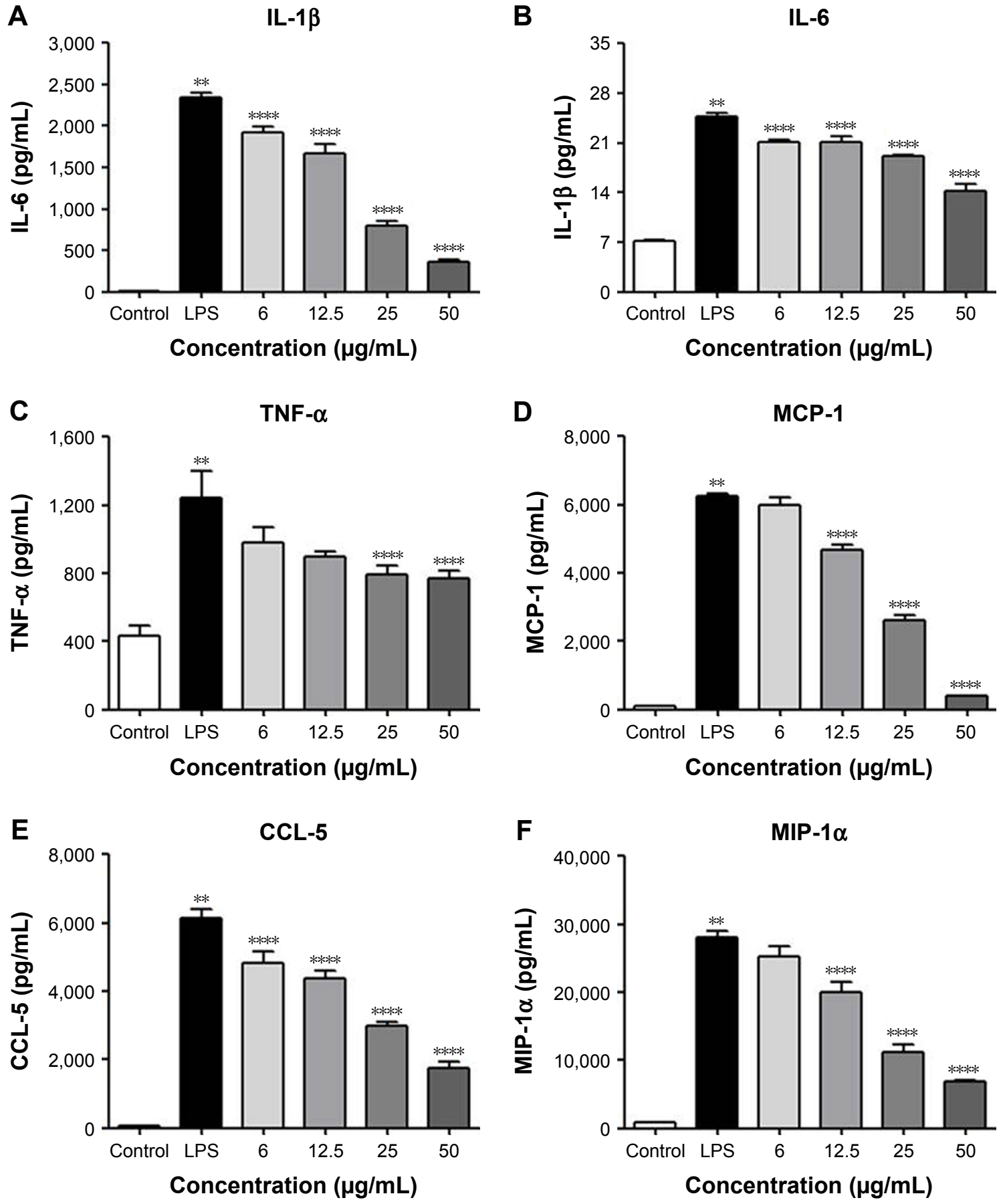

Figure 2 DCEO reduced the production of cytokines and chemokines in LPS-stimulated RAW264.7 cells.

Notes: Cells were incubated with indicated concentrations of DCEO for I h and then stimulated with LPS for 24 h. The production of IL-I $\beta$ (A), IL-6 (B), TNF- $\alpha$ (C), MCP-I (D), CCL-5 (E), and MIP-I $\alpha$ (F) was measured by ELISA. Data presented in bar charts are mean \pm SEM values from three independent experiments. ** $<<0.01$ vs unstimulated cells. $* * * * P<0.01$ vs LPS-stimulated cells determined by Dunnett's multiple comparisons test.

Abbreviations: DCEO, Dingchuan tang essential oil; LPS, lipopolysaccharide; IL-I $\beta$, interleukin-I $\beta$; IL-6, interleukin-6; TNF- $\alpha$, tumor necrosis factor- $\alpha$; MCP-I, monocyte chemoattractant protein-I; CCL-5, chemokine (C-C motif) ligand 5; MIP-I $\alpha$, macrophage inflammatory protein; ELISA, enzyme-linked immunosorbent assay; SEM, standard error of the mean.

LPS stimulation. DCEO treatment suppressed the phosphorylation of p65 and AP-1 (Figures 4B and 5B) in a concentration-dependent manner. Next, regulators upstream AP-1 and NF- $\kappa$ B were also examined. Figures $4 \mathrm{~A}$ and $5 \mathrm{~A}$ showed that phosphorylations of three key MAPKs subunits including p38, ERK, and JNK were markedly enhanced by LPS stimulation in RAW264.7 cells, and DCEO treatment inhibited the phosphorylation of p38, ERK, and JNK in a concentration-dependent manner (Figures 4A and 5A). Moreover, DCEO treatment markedly reduced LPS-induced 

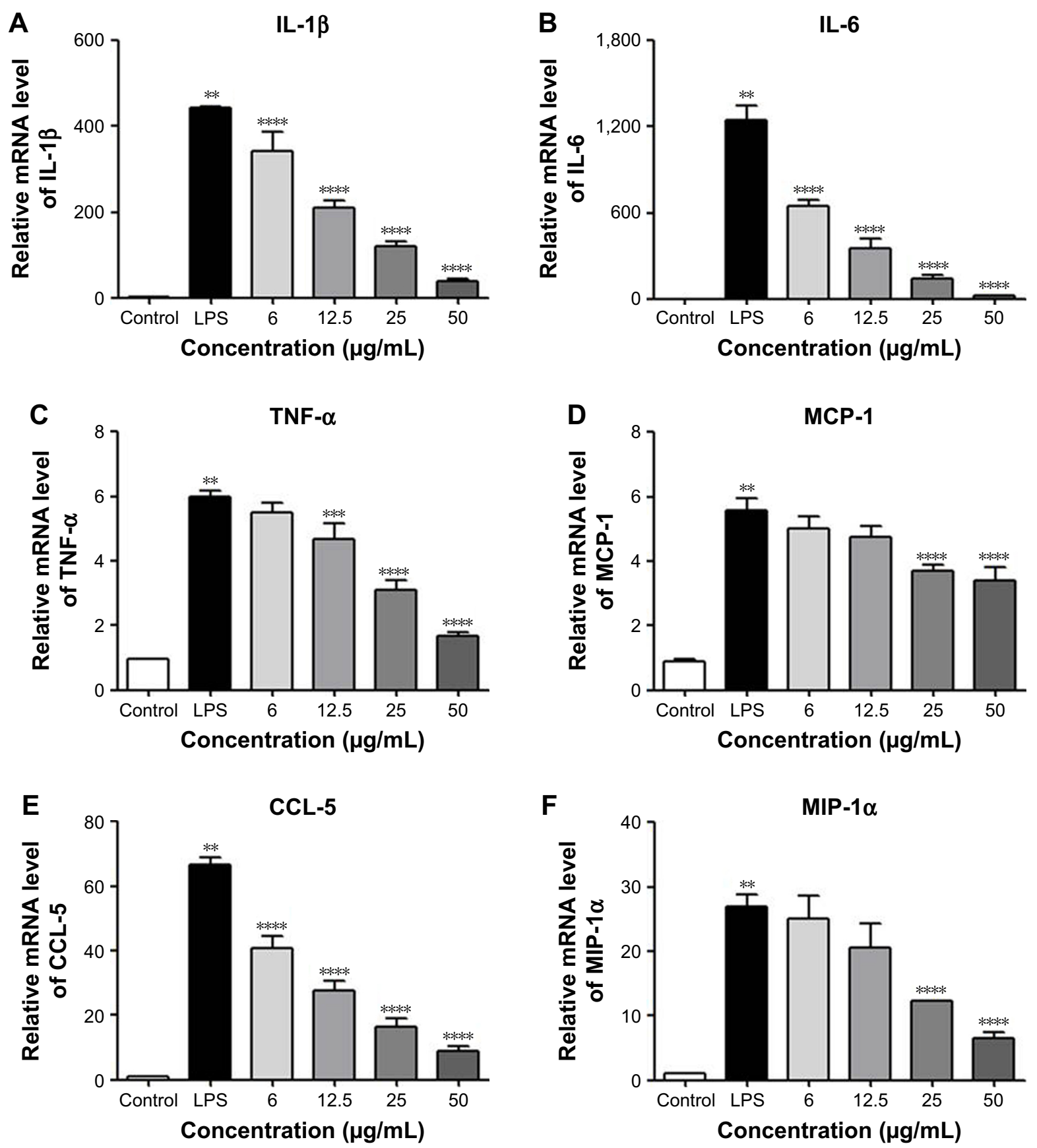

Figure 3 DCEO decreased mRNA levels of cytokines and chemokines in LPS-stimulated RAW264.7 cells.

Notes: Cells were incubated with indicated concentrations of DCEO for I h and then stimulated with LPS for $6 \mathrm{~h}$. The mRNA levels of IL-I $\beta$ (A), IL-6 (B), TNF- $\alpha$ (C), MCP-I (D), CCL-5 (E), and MIP-I $\alpha(\mathbf{F})$ were quantified by qRT-PCR. Data presented in bar charts are mean \pm SEM values from three independent experiments. **P $<0.0 \mathrm{I}$ vs unstimulated cells. $* * * P<0.05$ and $* * * * P<0.01$ vs LPS-stimulated cells determined by Dunnett's multiple comparisons test.

Abbreviations: DCEO, Dingchuan tang essential oil; LPS, lipopolysaccharide; IL-I $\beta$, interleukin-I $\beta$; IL-6, interleukin-6; TNF- $\alpha$, tumor necrosis factor- $\alpha$; MCP-I, monocyte chemoattractant protein-I; CCL-5, chemokine (C-C motif) ligand 5; MIP-I $\alpha$, macrophage inflammatory protein; qRT-PCR, quantitative real-time polymerase chain reaction; SEM, standard error of the mean.

phosphorylation of IкB $\alpha$. Phosphorylations of TAK1 and IKK $\alpha / \beta$ were significantly enhanced by LPS treatment, which could be suppressed by DCEO treatment in a concentrationdependent manner (Figures 4A and 5A). DCEO treatment also inhibited LPS-induced degradation of IRAK1 and IRAK4 (Figures 4A and 5A). Phosphatidylinositol 3-kinase
(PI3K)/Akt signaling also plays a role in LPS-triggered inflammatory response in macrophages. ${ }^{32}$ As shown in Figures 4B and 5B, phosphorylated PI3K subunits p 85 and Akt (ser473) were remarkably elevated after LPS stimulation in RAW264.7 macrophages, while DCEO suppressed the elevation in a concentration-dependent manner. While the 


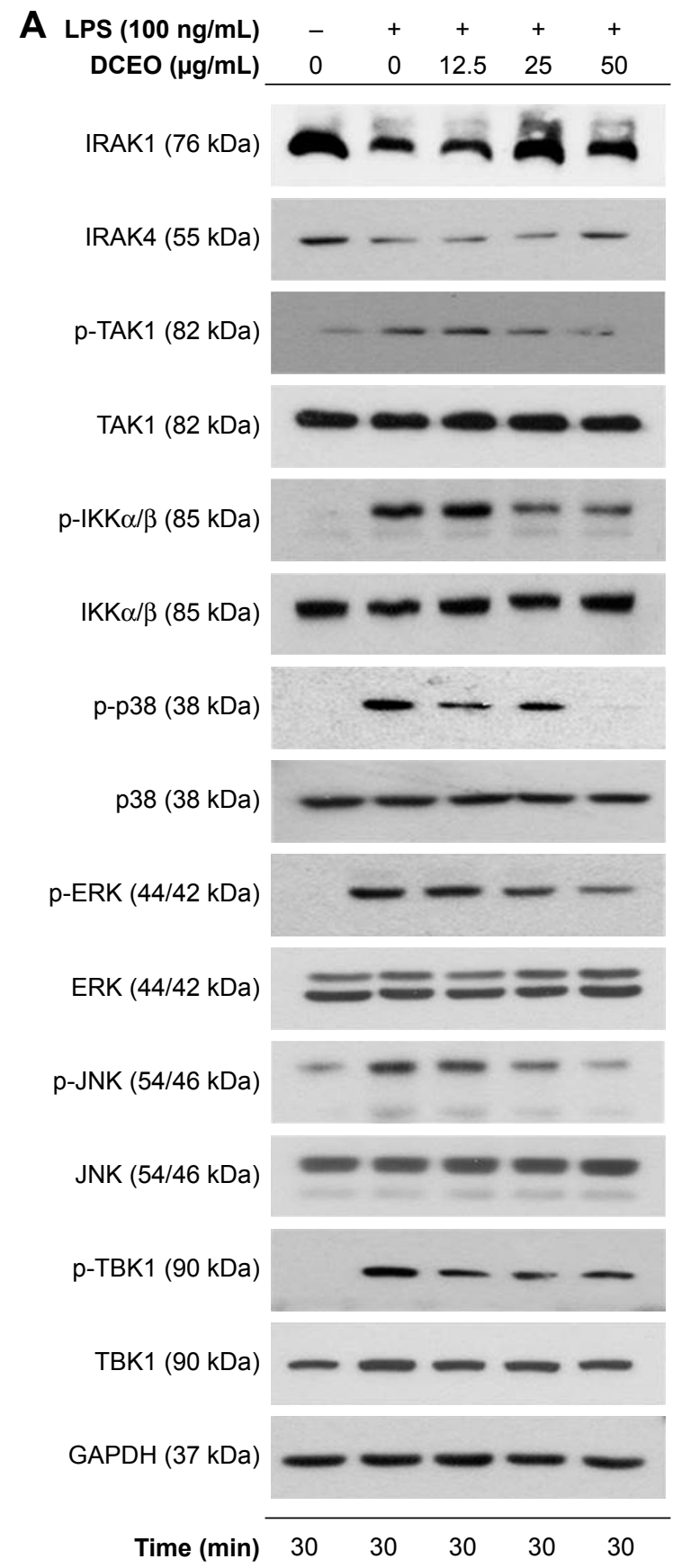

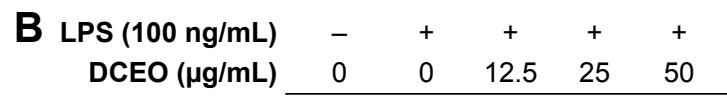

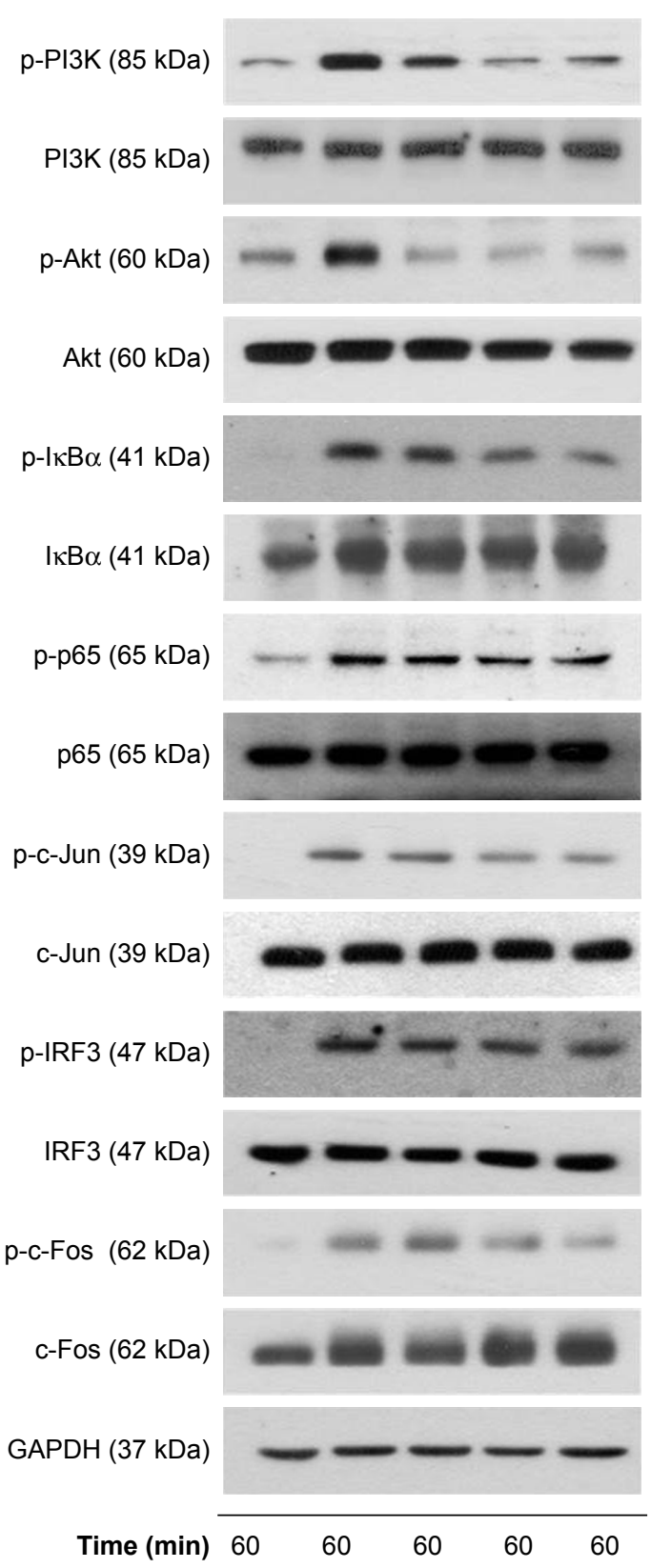

Figure 4 DCEO affected the molecular components of the IRAK/NF-KB, IRAK/AP-I, and TBKI/IRF3 pathways in LPS-stimulated RAW264.7 cells.

Notes: Cells were treated with DCEO at the indicated concentrations for I h and then stimulated with LPS for 30 or 60 min. Total and phosphorylated forms of individual proteins were detected by Western blot (A and $\mathbf{B})$. A representative of three independent experiments is shown.

Abbreviations: DCEO, Dingchuan tang essential oil; IRAK, interleukin-I receptor-associated kinase; NF-KB, nuclear factor-kappa B; AP-I, activator protein-I; TBKI, TANK-binding kinase I; IRF3, interferon regulatory factor 3; LPS, lipopolysaccharide; p, phosphorylated; JNK, c-Jun N-terminal kinase; ERK, extracellular signal-regulated kinase; p38, p38 mitogen-activated protein kinase; IKK $\alpha / \beta$, IKB kinase $\alpha / \beta$; TAKI, TGF $\beta$-activated kinase I; Akt, protein kinase B; PI3K, phosphatidylinositol 3-kinase.

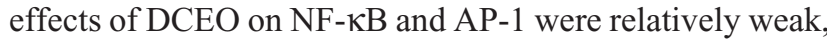
the underlying reasons will be explored in the future.

We also investigated the effects of DCEO on the TBK1/ IRF3 signaling pathway in RAW264.7 cells. As shown in Figures 4 and 5, the phosphorylation levels of TBK1 and IRF3 were obviously upregulated after LPS stimulation. DCEO treatment decreased the levels of phosphorylated
TBK1 and IRF3 in a concentration-dependent manner, suggesting an inhibitory effect of DCEO on TBK1/IRF3 signaling.

It has been reported that NF- $\mathrm{BB}, \mathrm{AP}-1$, and IRF3 are the key transcriptional factors in TLR4 signaling. Nuclear translocation of these transcription factors initiates the transcription of genes encoding proinflammatory mediators and 


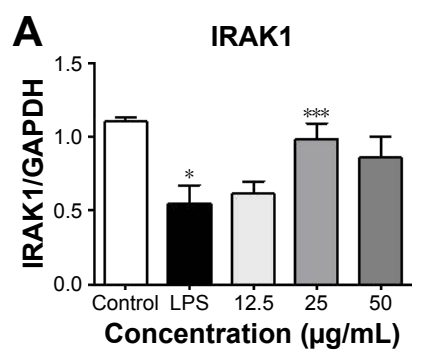

IRAK4
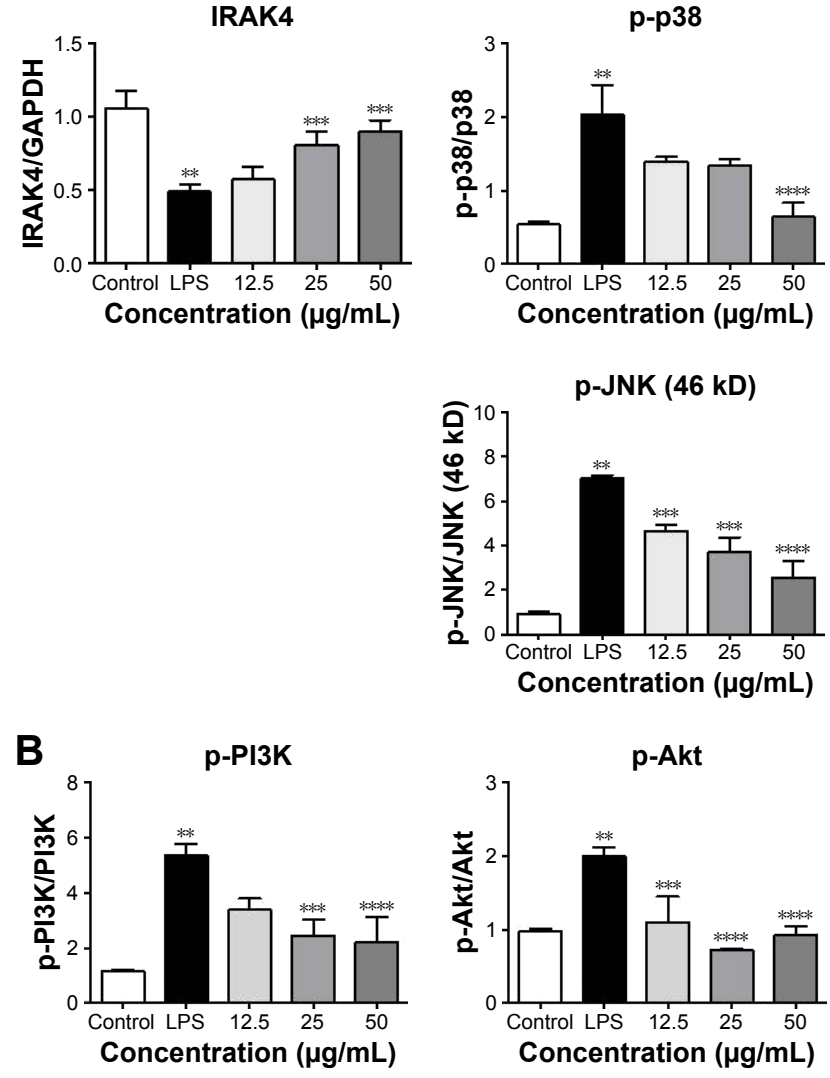
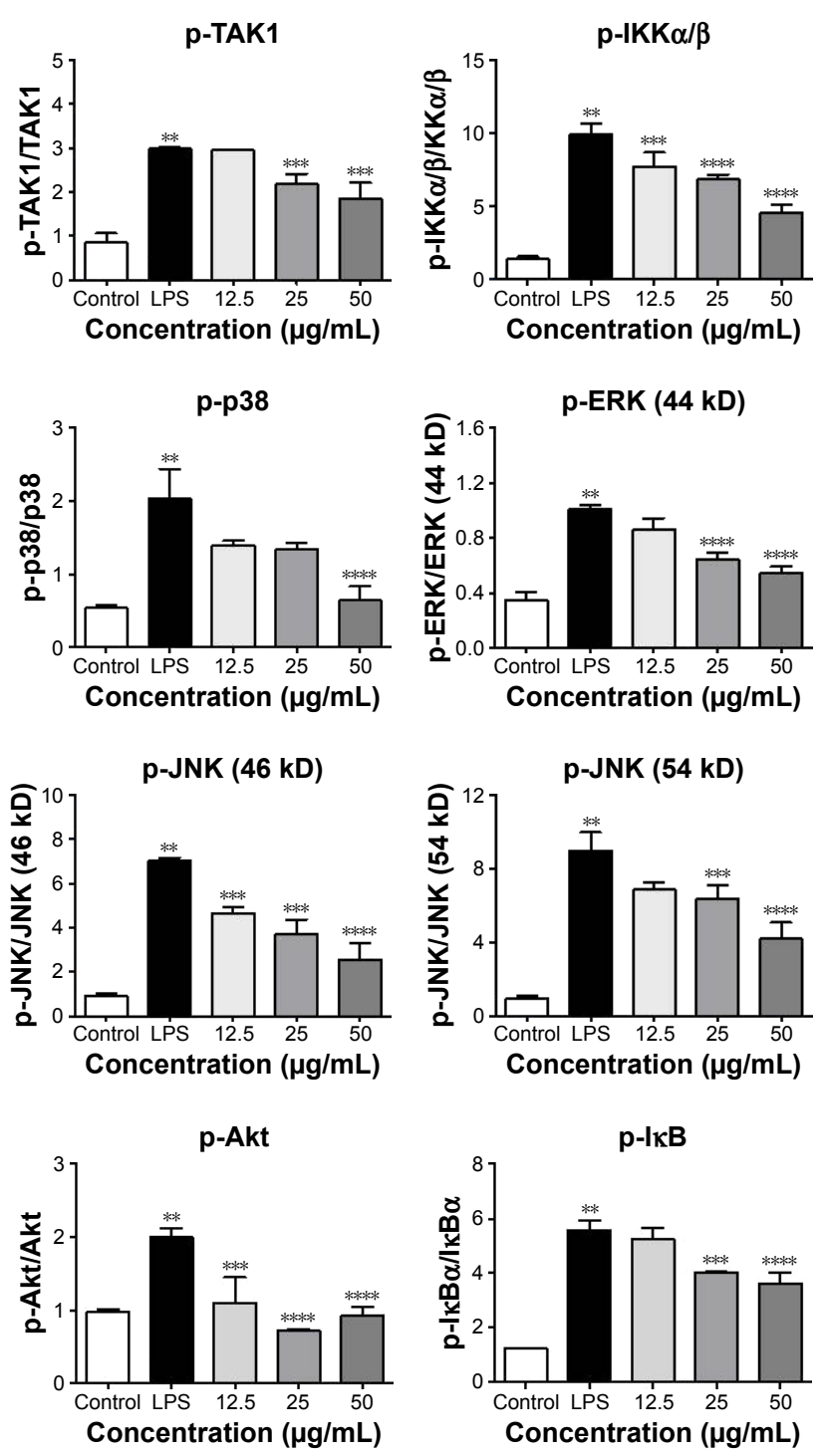

p-IKB

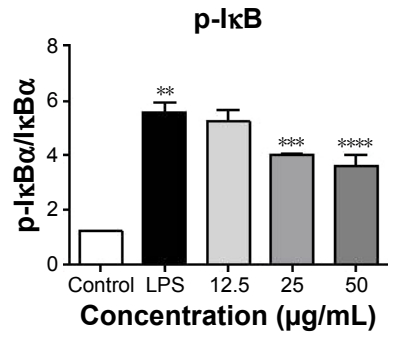

p-TBK1
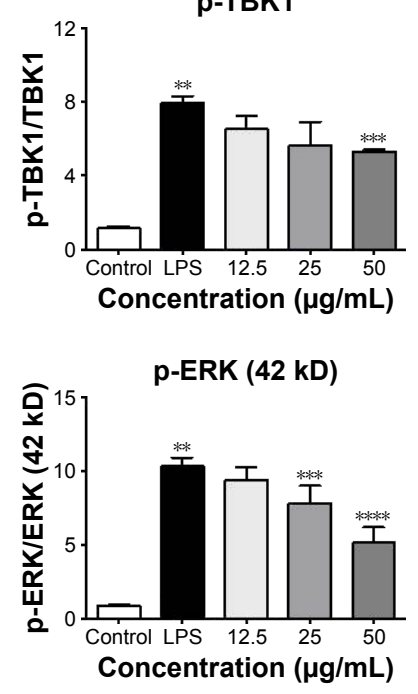
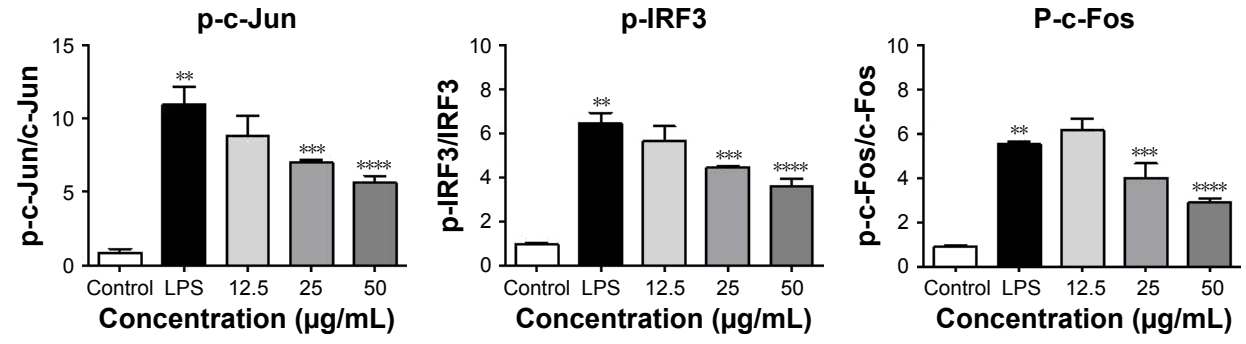

Figure 5 DCEO modulates the molecular components of the IRAK/NF-KB, IRAK/AP-I, and TBKI/IRF3 pathways in LPS-stimulated RAW264.7 cells.

Notes: Bar graphs show the ratio of (A) IRAKI/GAPDH, p-TAKI/TAKI, p-IKK $\alpha / \beta / / K K \alpha / \beta$, p-TBKI/TBKI, IRAK4/GAPDH, p-p38/p38, p-ERK/ERK, and p-JNK/JNK In RAW264.7 cells. (B) p-PI3K/PI3K, p-Akt/Akt, p-IKB/IkB, p-p65/p65, p-c-Jun/c-Jun, p-IRF3/IRF3, and p-c-Fos/c-Fos in RAW264.7 cells. Data are the mean \pm SEM of three independent experiments. $* P<0.05$ and $* * P<0.01$ vs unstimulated cells. $* * * P<0.05$ and $* * * * P<0.01$ vs LPS-stimulated cells determined by Dunnett's multiple comparisons test. Abbreviations: DCEO, Dingchuan tang essential oil; IRAK, interleukin-I receptor-associated kinase; NF- $\kappa B$, nuclear factor- kappa B; AP-I, activator protein-I; TBKI, TANK-binding kinase I; IRF3, interferon regulatory factor 3; LPS, lipopolysaccharide; $p$, phosphorylated; TAKI, TGF $\beta$-activated kinase I; IKK $\alpha / \beta$, IKB kinase $\alpha / \beta$; PI3K, phosphatidylinositol 3-kinase; Akt, protein kinase B; p38, p38 mitogen-activated protein kinase; ERK, extracellular signal-regulated kinase; JNK, c-Jun N-terminal kinase; SEM, standard error of the mean.

cytokines. ${ }^{33}$ As shown in Figure 6A and B, nuclear protein levels of IRF3, NF-KB heterodimer components (p65 and p50), and one of the AP-1 components (c-Jun) were markedly increased $60 \mathrm{~min}$ after LPS treatment. DCEO treatment inhibited the increment of nuclear IRF3, p65, p50, and c-Jun. Immunofluorescence staining of p65 confirmed the inhibitory effect of DCEO on NF- $\mathrm{KB}$ nuclear localization (Figure 7). 
A

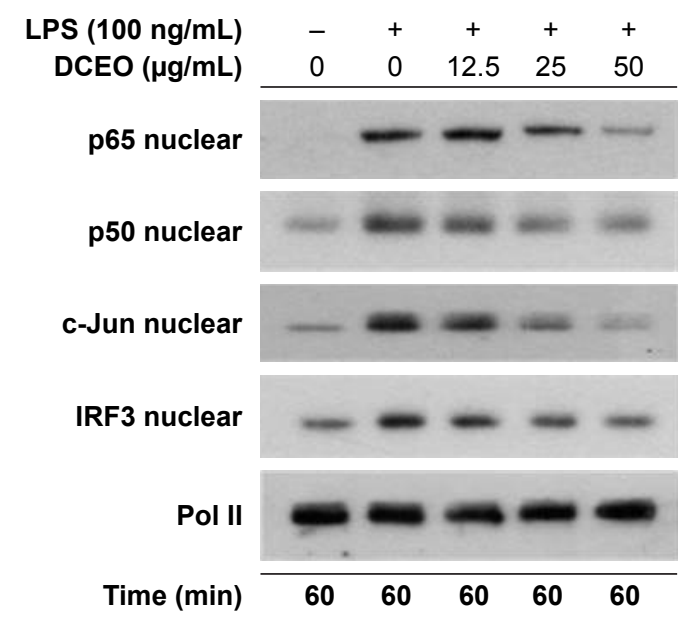

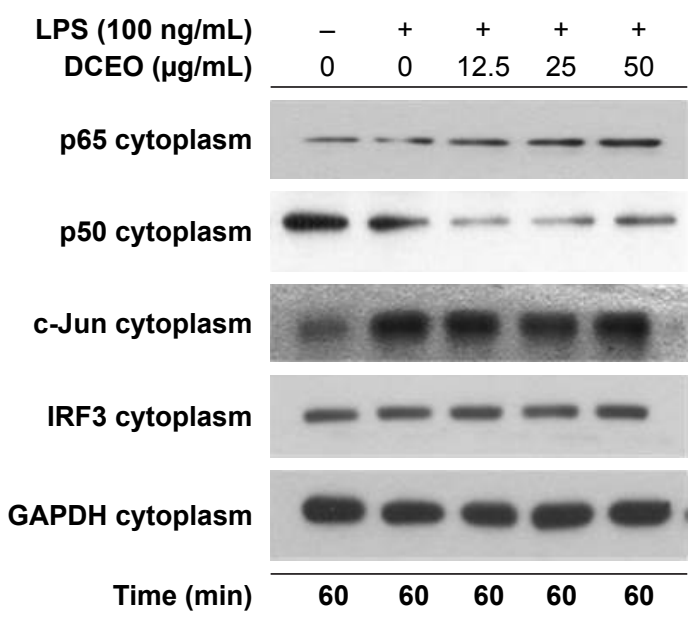

B

Nuclear protein
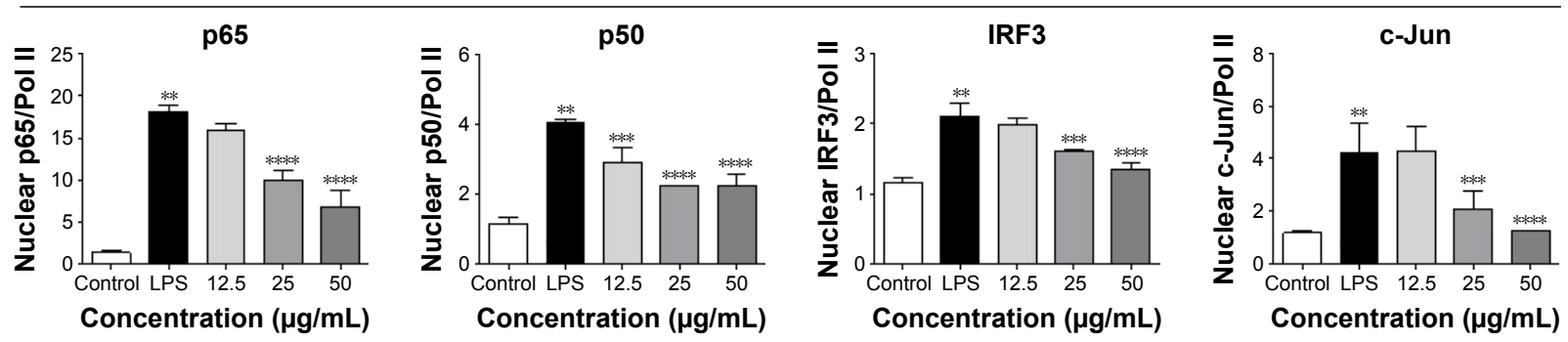

\section{Cytoplasmic protein}
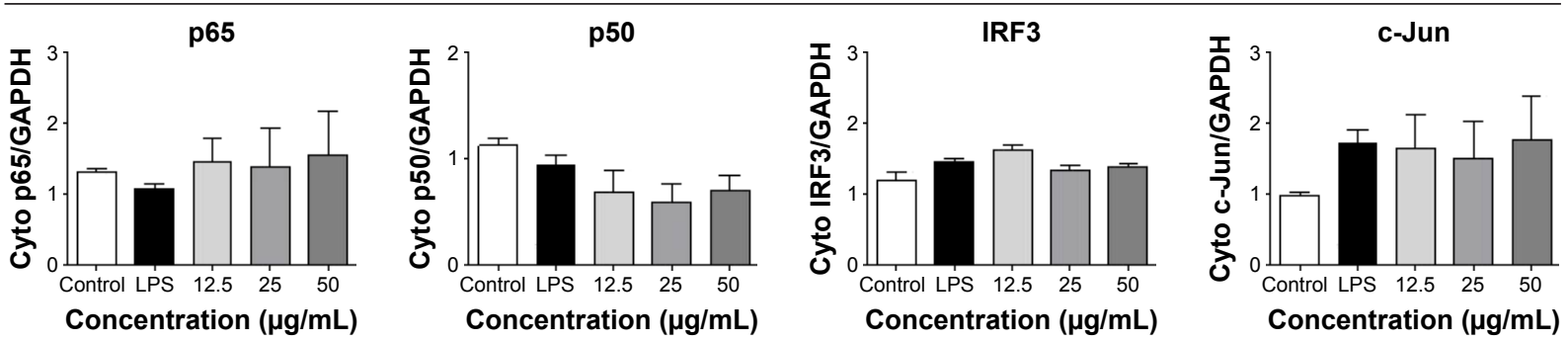

Figure 6 DCEO inhibited nuclear localization of NF-KB, AP-I, and IRF3 in LPS-stimulated RAW264.7 cells.

Notes: Cells were treated with DCEO with indicated concentrations for I h and then stimulated with LPS for 60 min. The cytoplasmic and nuclear protein levels of NFKB (p65 and p50), c-Jun, and IRF3 were determined by Western blot (A). Bar graphs show the relative levels of cytoplasmic and nuclear p65, p50, IRF3, and c-Jun. Data are the mean SEM of three independent experiments. ${ }^{* *} P<0.01$ vs unstimulated cells. ${ }^{* * *} P<0.05$ and $* * * * P<0.0$ I vs LPS-stimulated cells determined by Dunnett's multiple comparisons test (B).

Abbreviations: DCEO, Dingchuan tang essential oil; NF-KB, nuclear factor-kappa B; AP-I, activator protein-I; IRF3, interferon regulatory factor 3; LPS, lipopolysaccharide; SEM, standard error of the mean.

\section{Discussion}

In the present study, 27 compounds were identified in DCEO using the GC-MS analysis. The main constituents of DCEO, such as benzaldehyde, $\alpha$-terpineol, $n$-hexadecanoic acid and oleic acid, have been reported to possess strong anti-inflammatory effects. ${ }^{34-37} n$-hexadecanoic acid inhibits the activity of phospholipase A2 to control inflammation. ${ }^{34}$ $\alpha$-Terpineol reduces IL- 6 formation through binding to the IL-6 receptor and subsequent internalization of the entire ligand-receptor complex. ${ }^{35}$ Benzaldehyde exhibits anti-asthmatic effect via downregulating the production of proinflammatory cytokines. ${ }^{36}$ Oleic acid exerts anti-arthritic effect by reducing inflammatory cell infiltration. ${ }^{37}$ These reports imply that the inflammatory mediator inhibitory effect of DCEO may be, at least in part, due to the presence of these compounds. Further studies are needed to identify active constituents inside DCEO.

It is well known that NO and PGE2 are two key mediators of inflammatory responses. ${ }^{38}$ Excessive NO production, especially by macrophages, can lead to cytotoxicity, inflammation, and autoimmune disorders. ${ }^{39,40}$ PGE2 is a metabolite of arachidonic acid that elicits a wide range of physiological and pathological processes, such as gastrointestinal protection, inflammation, and cancer. ${ }^{41}$ PGE2 mediates the onset 


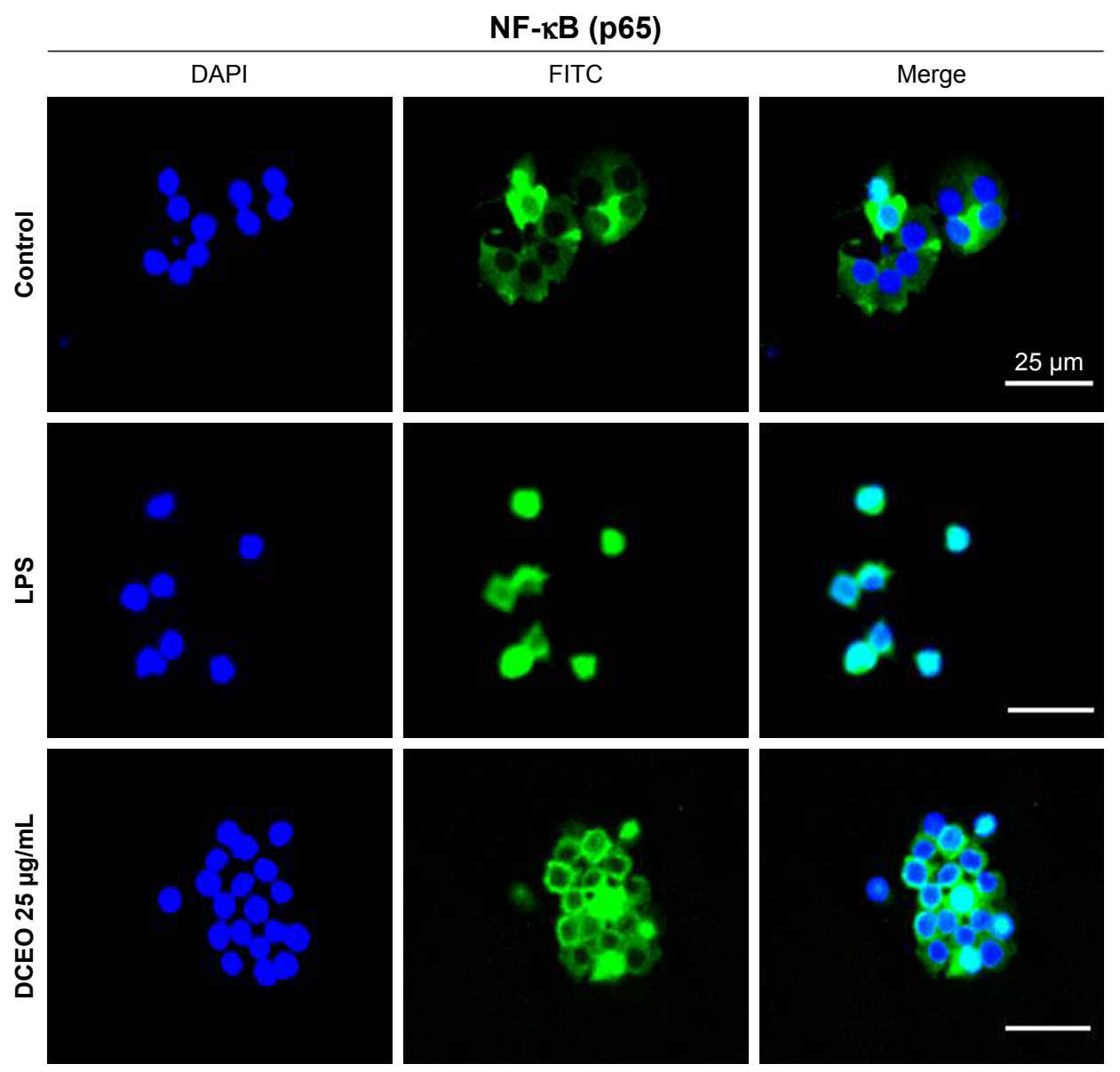

Figure 7 DCEO inhibited nuclear localization of NF- $\kappa B$ in LPS-stimulated RAW264.7 cells.

Notes: Cells were treated with DCEO with indicated concentrations for I h and then stimulated with LPS for 60 min. The subcellular localization of NF- $\mathrm{kB}$ (p65) was detected using immunofluorescence assay, and the images were acquired using the Leica DM 2500 fluorescent microscope. Bar represents $25 \mu \mathrm{m}$.

Abbreviations: DCEO, Dingchuan tang essential oil; NF-кB, nuclear factor-kappa B; LPS, lipopolysaccharide.

of the symptoms of classic signs of inflammation, including redness, swelling, and pain. ${ }^{42}$ Hence, measuring the production of LPS-induced NO and PGE2 can evaluate the progression of inflammation, and inhibition of their production might have potential therapeutic value for controlling inflammatory reactions and diseases. In the present study, we examined the effects of DCEO on the production of NO and PGE2. We observed that DCEO remarkably suppressed LPS-induced release of NO and PGE2 in RAW264.7 cells, suggesting that DCEO has potential anti-inflammatory activity. Since iNOS and COX-2 catalyze the production of NO and PGE2, respectively, in activated macrophages, ${ }^{43,44}$ we determined the expression of iNOS and COX-2 in LPSstimulated RAW264.7 cells. It was found that upon stimulation, the mRNA and protein levels of iNOS and COX-2 were markedly increased and DCEO lowered mRNA and protein levels of iNOS and COX-2 in a concentration-dependent manner. These results suggest that DCEO suppresses NO and PGE2 production through inhibiting the expression of iNOS and COX-2, respectively. Further studies will be conducted to investigate the effect of DCEO on the activities of these two enzymes. In addition to PGE2 and COX-2, leukotriene and 5-lipoxygenase also play an important role in the arachidonic acid metabolic pathway and are linked to asthma pathogenesis. ${ }^{45}$ In the future, we will investigate the impact of DCEO on leukotriene formation and 5-lipoxygenase activity.

LPS-activated macrophages release proinflammatory cytokines and chemokines that exacerbate inflammatory responses and lead to tissue injury. ${ }^{46}$ Proinflammatory cytokines, such as IL-1 $\beta$, IL-6, and TNF- $\alpha$, play crucial roles in the pathogenesis of various acute and chronic inflammatory conditions including allergic asthma, infection, and rheumatoid arthritis. ${ }^{47-49}$ Chemokines are a family of chemoattractant molecules that have a role in neutrophil, eosinophil, and monocyte migration during acute and chronic inflammation. ${ }^{50}$ Our data indicate that DCEO treatment significantly inhibits LPS-induced release of TLR4-regulated cytokines (IL-1 $\beta$, 
IL-6, and TNF- $\alpha$ ) and chemokines (MCP-1, MIP-1 $\alpha$, and CCL-5) in RAW264.7 cells. Based on these data, it can be concluded that DCEO has inhibitory effect on inflammatory mediators in LPS-stimulated RAW264.7 cells.

TLR4 is the primary recognition molecule for inflammatory responses initiated by LPS. ${ }^{51}$ After ligation with LPS, TLR4 recruits intracellular adapters including MyD88, an adaptor recruits IRAK4, thereby allowing the phosphorylation and degradation of IRAK $1 .{ }^{29}$ This leads to the ubiquitination of TRAF6 and induces the activation of TAK1, which in turn phosphorylates the IKK complex (including IKK $\alpha$, IKK $\beta$, and IKK $\gamma$ ). ${ }^{52}$ The activated IKK complex then phosphorylates $I \kappa B$, which leads to its ubiquitination and subsequent degradation. ${ }^{53,54}$ Removal of IкBs liberates

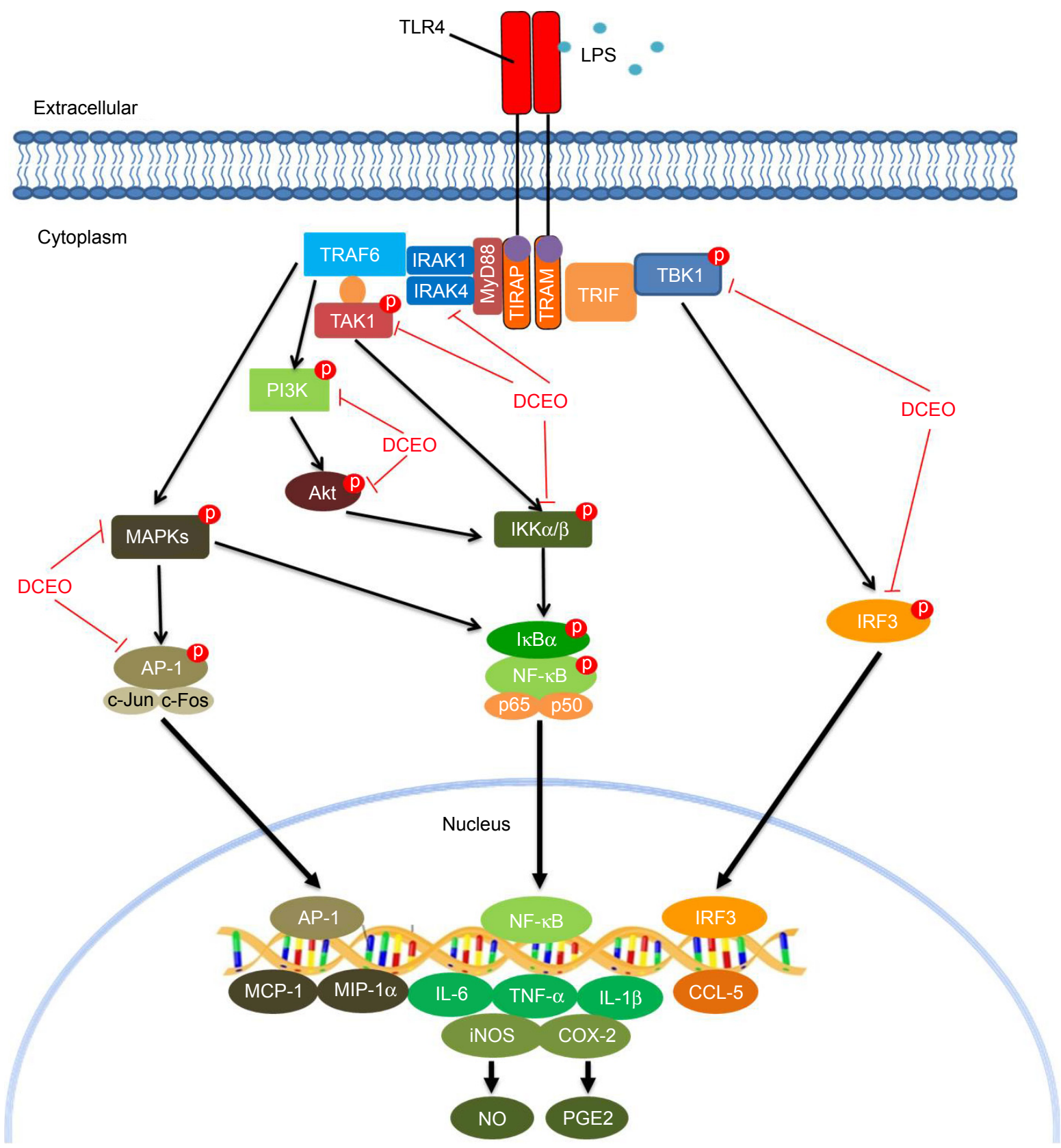

Figure 8 A schematic diagram showing the association of IRAK/NF-KB, IRAK/AP-I, and TBKI/IRF3 signaling inhibition with the inhibitory effects of DCEO on inflammatory mediators.

Abbreviations: IRAK, interleukin-I receptor-associated kinase; NF- KB, nuclear factor-kappa B; AP-I, activator protein-I; TBKI, TANK-binding kinase I; IRF3, interferon regulatory factor 3; DCEO, Dingchuan tang essential oil; NO, nitric oxide; PGE2, prostaglandin E2; iNOS, inducible nitric oxide synthase; COX-2, cyclooxygenase-2; MCP-I, monocyte chemoattractant protein-I; MIP-I $\alpha$, macrophage inflammatory protein; IL-6, interleukin-6; TNF- $\alpha$, tumor necrosis factor- $\alpha$; IL-I $\beta$, interleukin-I $\beta$; CCL-5, chemokine (C-C motif) ligand 5; IKK $\alpha / \beta$, IKB kinase $\alpha / \beta$; Akt, protein kinase B; PI3K, phosphatidylinositol 3-kinase; TAKI, TGF $\beta$-activated kinase I; MyD88, myeloid differentiation factor 88; TLR4, toll-like receptor 4; LPS, lipopolysaccharide. 
$\mathrm{NF}-\kappa \mathrm{B}$ for nuclear translocation and binding to cognate DNA binding sites to regulate the transcription of a number of genes that encode cytokines, chemokines, and stress response proteins. ${ }^{55}$ Our results show that DCEO treatment inhibits the phosphorylation and nuclear localization of $\mathrm{NF}-\kappa \mathrm{B}$ in LPS-stimulated RAW264.7 cells. We also found that the phosphorylation levels of $\mathrm{I} \kappa \mathrm{B} \alpha$ and $\mathrm{IKK} \alpha / \beta$ were decreased by DCEO treatment, indicating DCEO inhibits IKK $\alpha / \beta / \mathrm{I} \kappa \mathrm{B} \alpha / \mathrm{NF}-\kappa \mathrm{B}$ signaling. IRAK4, IRAK1, and TAK1 take part in the activation of IKKs and MAPKs. ${ }^{56}$ We found that the level of phosphorylated TAK1 was downregulated by DCEO treatment. We also found that DCEO treatment obviously reduces LPS-mediated degradation of IRAK1 and IRAK4, indicating an inhibitory effect of DCEO on IRAK/TAK1 signaling.

PI3K and its downstream kinase Akt appear to be important components of LPS-induced activation of the NF- $\kappa \mathrm{B}$ signaling pathway. ${ }^{57}$ Upon exposure to LPS, PI3K interacts with TRAF6 and actives the downstream target Akt. ${ }^{58}$ The activated Akt phosphorylates IKK $\alpha$, leading to I $\kappa$ B degradation and NF- $\kappa B$ translocation to the nucleus and resulting in specific cytokine gene expression. ${ }^{59}$ Consistent with a previous report, ${ }^{57}$ our study indicates that the phosphorylated PI3K subunit p85 and Akt (Ser473) are markedly elevated following LPS stimulation. DCEO treatment suppresses the phosphorylation of p85 and Akt in LPS-treated RAW264.7 cells, suggesting that DCEO inhibits LPS-triggered PI3K/ Akt signaling, which may, at least partially, contribute to the suppressive effect of DCEO on NF- $\kappa \mathrm{B}$ signaling.

Other than NF-אB, the AP-1 complex (composed of c-Fos and c-Jun subunits) also plays a critical role in the transcriptional regulation of genes that encode inflammatory mediators. ${ }^{60}$ In addition to the role in posttranslational regulation of NF- $\kappa \mathrm{B},{ }^{61} \mathrm{MAPK}$ regulate the transcriptional activity and half-life of AP-1. ${ }^{62}$ Therefore, we also investigated the effect of DCEO on MAPKs and AP-1 activities. Results showed that the LPS-stimulated phosphorylation of MAPKs (ERK, p38, and JNK) and AP-1 (c-Jun and c-Fos) was suppressed by DCEO treatment, indicating that DCEO inhibits the MAPKs/NF- $\mathrm{KB}$ and MAPKs/AP-1 signaling pathways.

Besides MyD88-dependent pathways, the TRIF-dependent pathway also plays a role in LPS-induced inflammatory response in macrophages. ${ }^{63}$ LPS can also trigger TRIF signaling that activates TBK1, which in turn phosphorylates IRF3 and triggers its dimerization and nuclear translocation, leading to the expression of IFN- $\beta$ and CCL-5. ${ }^{64,65}$ In our present study, DCEO treatment inhibits LPS-induced phosphorylation and nuclear localization of IRF3. The results are in agreement with the inhibitory effect of DCEO on CCL-5 production. We then examined the effects of DCEO on the phosphorylation of TBK1 that is upstream of IRF3 and found that DCEO reduced the phosphorylation of TBK1, suggesting that DCEO inhibits TBK1/IRF3 signaling.

\section{Conclusion}

In this study, we found that suppression of the IRAK/NF- $\mathrm{RB}$, IRAK/AP-1, and TBK1/IRF3 signaling pathways is associated with the inhibitory effect of DCEO on inflammatory mediators in LPS-stimulated RAW264.7 macrophages (Figure 8). These findings provide a pharmacological justification for the use of Dingchuan tang in managing inflammatory disorders, as Dingchuan tang is traditionally used for treating asthma, which is typically characterized by an eosinophilic inflammation. ${ }^{13,66}$ In the future, we will use asthma models to determine the impact of DCEO on eosinophilic inflammation.

\section{Acknowledgments}

This study was supported by grants from Science, Technology and Innovation Commission of Shenzhen (JCYJ20170817173608483 and JCYJ20160229210327924); National Natural Science Foundation of China (81673649); Natural Science Foundation of Guangdong Province (2016A030313007); Research Grants Council of Hong Kong (GRF12125116); Hong Kong Baptist University (FRG1/16-17/048 and FRG2/17-18/032); Fundamental Research Funds for the Central Universities (2017-JYB-JS057); and a contract research grant from Defond Electrical Industries Limited.

\section{Disclosure}

The authors report no conflicts of interest in this work.

\section{References}

1. Turner MD, Nedjai B, Hurst T, Pennington DJ. Cytokines and chemokines: at the crossroads of cell signalling and inflammatory disease. Biochim Biophys Acta. 2014;1843(11):2563-2582.

2. O'Neill LAJ. Targeting signal transduction as a strategy to treat inflammatory diseases. Nat Rev Drug Discov. 2006;5(7):549-563.

3. Jacobs P, Bissonnette R, Guenther LC. Socioeconomic burden of immune-mediated inflammatory diseases - focusing on work productivity and disability. J Rheumatol. 2011;38:55-61.

4. Fujiwara N, Kobayashi K. Macrophages in inflammation. Curr Drug Targets Inflamm Allergy. 2005;4(3):281-286.

5. Meng FY, Lowell CA. Lipopolysaccharide (LPS)-induced macrophage activation and signal transduction in the absence of Src-family kinases Hck, Fgr, and Lyn. J Exp Med. 1997;185(9):1661-1670.

6. Fitzgerald KA, Rowe DC, Barnes BJ, et al. LPS-TLR4 signaling to IRF-3/7 and NF-kappaB involves the toll adapters TRAM and TRIF. J Exp Med. 2003;198(7):1043-1055. 
7. Reis J, Guan XQ, Kisselev AF, et al. LPS-induced formation of immunoproteasomes: TNF-alpha and nitric oxide production are regulated by altered composition of proteasome-active sites. Cell Biochem Biophys. 2011;60(1-2):77-88.

8. Rossol M, Heine H, Meusch U, et al. LPS-induced cytokine production in human monocytes and macrophages. Crit Rev Immunol. 2011; 31(5):379-446.

9. Laskin DL, Sunil VR, Gardner CR, Laskin JD. Macrophages and tissue injury: agents of defense or destruction? Annu Rev Pharmacol Toxicol. 2011;51:267-288

10. Matsukawa A, Yoshinaga M. Sequential generation of cytokines during the initiative phase of inflammation, with reference to neutrophils. Inflamm Res. 1998;47(suppl 3):S137-S144.

11. Wang N, Li J, Huang X, Chen W, Chen Y. Herbal medicine cordyceps sinensis improves health-related quality of life in moderate-to-severe asthma. Evid Based Complement Alternat Med. 2016;2016:6134593.

12. Li XM, Brown L. Efficacy and mechanisms of action of traditional Chinese medicines for treating asthma and allergy. J Allergy Clin Immunol. 2009;123(2):297-306; quiz307-298.

13. Chan CK, Kuo ML, Shen JJ, See LC, Chang HH, Huang JL. Ding Chuan Tang, a Chinese herb decoction, could improve airway hyperresponsiveness in stabilized asthmatic children: a randomized, doubleblind clinical trial. Pediatr Allergy Immunol. 2006;17(5):316-322.

14. Wang HM, Lin SK, Yeh CH, Lai JN. Prescription pattern of Chinese herbal products for adult-onset asthma in Taiwan: a population-based study. Ann Allergy Asthma Immunol. 2014;112(5):465-470.

15. Huang TP, Liu PH, Lien ASY, Yang SL, Chang HH, Yen HR. Characteristics of traditional Chinese medicine use in children with asthma: a nationwide population-based study. Allergy. 2013;68(12): 1610-1613.

16. Liu L, Liu ZW. Essentials of Chinese Medicine. Vol. 2. Dordrecht, Heidelberg, London, New York: Springer; 2009:417-418.

17. Kao ST, Chang CH, Chen YS, Chiang SY, Lin JG. Effects of DingChuan-Tang on bronchoconstriction and airway leucocyte infiltration in sensitized guinea pigs. Immunopharmacol Immunotoxicol. 2004; 26(1):113-124.

18. Lin MY, Chian SY, Wu HC, Hsu CD. Anti-inflammatory effect of Ding Chuan Tang in human lung epithelial cells. Taiwan J Clin Chin Med 2009;15(2):97-110.

19. Kim S, Jung E, Shin S, et al. Anti-inflammatory activity of Camellia japonica oil. BMB Rep. 2012;45(3):177-182.

20. Shen CY, Zhang TT, Zhang WL, Jiang JG. Anti-inflammatory activities of essential oil isolated from the calyx of Hibiscus sabdariffa L. Food Funct. 2016;7(10):4451-4459.

21. Wang CM, Sun JB, Li H, Yang X, Liu HM, Chen JG. In vivo antiinflammatory activities of the essential oil from Radix Angelicae dahuricae. J Nat Med. 2016;70(3):563-570.

22. Nogueira MNM, Aquino SG, Rossa C, Spolidorio DMP. Terpinen-4-ol and alpha-terpineol (tea tree oil components) inhibit the production of IL-1 beta, IL-6 and IL-10 on human macrophages. Inflamm Res. 2014; 63(9):769-778.

23. Schaeffler A, Gross P, Buettner R, et al. Fatty acid-induced induction of toll-like receptor-4/nuclear factor-kappa B pathway in adipocytes links nutritional signalling with innate immunity. Immunology. 2009; 126(2):233-245.

24. Clevenger JF. Apparatus for the determination of volatile oil. J Am Pharm Assoc. 1928;17(4):345-349.

25. Cheng BCY, Yu H, Su T, et al. A herbal formula comprising Rosae Multiflorae Fructus and Lonicerae Japonicae Flos inhibits the production of inflammatory mediators and the IRAK-1/TAK1 and TBK1/IRF3 pathways in RAW 264.7 and THP-1 cells. J Ethnopharmacol. 2015;174:195-199.

26. Cheng BCY, Ma XQ, Kwan HY, et al. A herbal formula consisting of Rosae Multiflorae Fructus and Lonicerae Japonicae Flos inhibits inflammatory mediators in LPS-stimulated RAW 264.7 macrophages. J Ethnopharmacol. 2014;153(3):922-927.

27. Aktan F. iNOS-mediated nitric oxide production and its regulation. Life Sci. 2004;75(6):639-653.
28. Pang L, Knox AJ. PGE2 release by bradykinin in human airway smooth muscle cells: involvement of cyclooxygenase-2 induction. Am J Physiol. 1997;273(6 pt 1):L1132-L1140.

29. Lu YC, Yeh WC, Ohashi PS. LPS/TLR4 signal transduction pathway. Cytokine. 2008;42(2):145-151.

30. Su T, Yu H, Kwan HY, et al. Comparisons of the chemical profiles, cytotoxicities and anti-inflammatory effects of raw and rice wine-processed Herba Siegesbeckiae. J Ethnopharmacol. 2014;28(156):365-369.

31. Gomes MTR, Campos PC, de Almeida LA, et al. The role of innate immune signals in immunity to Brucella abortus. Front Cell Infect Microbiol. 2012;2:130.

32. O'Neill LAJ, Bowie AG. The family of five: TIR-domain-containing adaptors in toll-like receptor signalling. Nat Rev Immunol. 2007;7(5): 353-364.

33. Zhong B, Tien P, Shu HB. Innate immune responses: crosstalk of signaling and regulation of gene transcription. Virology. 2006;352(1): 14-21

34. Aparna V, Dileep KV, Mandal PK, Karthe P, Sadasivan C, Haridas M. Anti-inflammatory property of n-Hexadecanoic acid: structural evidence and kinetic assessment. Chem Biol Drug Des. 2012;80(3):434-439.

35. Held S, Schieberle P, Somoza V. Characterization of alpha-terpineol as an anti-inflammatory component of orange juice by in vitro studies using oral buccal cells. J Agric Food Chem. 2007;55(20):8040-8046.

36. Jang TY, Park CS, Kim KS, Heo MJ, Kim YH. Benzaldehyde suppresses murine allergic asthma and rhinitis. Int Immunopharmacol. 2014; 22(2):444-450.

37. Pérez-Martínez P, Hernández V, Rodríguez-Espinosa O, Arce-Paredes $\mathrm{P}$, Rojas-Espinosa O. Differential anti-inflammatory effects of three purified omega unsaturated fatty acids on collagen-induced arthritis in mouse. Mod Res Inflamm. 2016;5(3):31-44.

38. Wallace JL. Nitric oxide as a regulator of inflammatory processes. Mem Inst Oswaldo Cruz. 2005;100:5-9.

39. Grabowski PS, Wright PK, VanTHof RJ, Helfrich MH, Ohshima H, Ralston SH. Immunolocalization of inducible nitric oxide synthase in synovium and cartilage in rheumatoid arthritis and osteoarthritis. $\mathrm{BrJ}$ Rheumatol. 1997;36(6):651-655.

40. Hibbs JB Jr, Taintor RR, Vavrin Z, Rachlin EM. Nitric oxide: a cytotoxic activated macrophage effector molecule. Biochem Biophys Res Commun. 1988;157(1):87-94.

41. Nakanishi M, Rosenberg DW. Multifaceted roles of PGE2 in inflammation and cancer. Semin Immunopathol. 2013;35(2):123-137.

42. Ricciotti E, FitzGerald GA. Prostaglandins and inflammation. Arterioscler Thromb Vasc Biol. 2011;31(5):986-1000.

43. Chi DS, Qui M, Krishnaswamy G, Li CF, Stone W. Regulation of nitric oxide production from macrophages by lipopolysaccharide and catecholamines. Nitric Oxide. 2003;8(2):127-132.

44. Park JY, Pillinger MH, Abramson SB. Prostaglandin E2 synthesis and secretion: the role of PGE2 synthases. Clin Immunol. 2006;119(3): 229-240.

45. Hedi H, Norbert G. 5-lipoxygenase pathway, dendritic cells, and adaptive immunity. J Biomed Biotechnol. 2004;2004(2):99-105.

46. Devkota S, Chang EB. Nutrition, microbiomes, and intestinal inflammation. Curr Opin Gastroenterol. 2013;29(6):603-607.

47. Barnes PJ. The cytokine network in asthma and chronic obstructive pulmonary disease. J Clin Invest. 2008;118(11):3546-3556.

48. Geneva-Popova M, Murdjeva M. Study on proinflammatory cytokines (IL-1 beta, IL-6, TNF-alpha) and IL-2 in patients with acute hepatitis B. Folia Med (Plovdiv). 1999;41(1):78-81.

49. Mori T, Miyamoto T, Yoshida H, et al. IL-1 beta and TNF alpha-initiated IL-6-STAT3 pathway is critical in mediating inflammatory cytokines and RANKL expression in inflammatory arthritis. Int Immunol. 2011; 23(11):701-712.

50. Conti P, DiGioacchino MD. MCP-1 and RANTES are mediators of acute and chronic inflammation. Allergy Asthma Proc. 2001;22(3): 133-137.

51. Park BS, Lee JO. Recognition of lipopolysaccharide pattern by TLR4 complexes. Exp Mol Med. 2013;45:e66. 
52. Sun LJ, Deng L, Ea CK, Xia ZP, Chen ZJJ. The TRAF6 ubiquitin ligase and TAK1 kinase mediate IKK activation by BCL10 and MALT1 in T lymphocytes. Mol Cell. 2004;14(3):289-301.

53. Oeckinghaus A, Ghosh S. The NF-kappaB family of transcription factors and its regulation. Cold Spring Harb Perspect Biol. 2009;1(4): a000034.

54. Viatour P, Merville MP, Bours V, Chariot A. Phosphorylation of NFkappaB and IkappaB proteins: implications in cancer and inflammation. Trends Biochem Sci. 2005;30(1):43-52.

55. Verma IM. Nuclear factor (NF)-kappaB proteins: therapeutic targets. Ann Rheum Dis. 2004;63(suppl 2):ii57-ii61.

56. Cui W, Xiao N, Xiao H, et al. Beta-TrCP-mediated IRAK1 degradation releases TAK1-TRAF6 from the membrane to the cytosol for TAK1-dependent NF-kappaB activation. Mol Cell Biol. 2012;32(19): 3990-4000.

57. Ojaniemi M, Glumoff V, Harju K, Liljeroos M, Vuori K, Hallman M. Phosphatidylinositol 3-kinase is involved in toll-like receptor 4-mediated cytokine expression in mouse macrophages. Eur J Immunol. 2003; 33(3):597-605.

58. Wong F, Hull C, Zhande R, Law J, Karsan A. Lipopolysaccharide initiates a TRAF6-mediated endothelial survival signal. Blood. 2004; 103(12):4520-4526.
59. Ozes ON, Mayo LD, Gustin JA, Pfeffer SR, Pfeffer LM, Donner DB. NF-kappaB activation by tumour necrosis factor requires the Akt serinethreonine kinase. Nature. 1999;401(6748):82-85.

60. Zenz R, Eferl R, Scheinecker C, et al. Activator protein 1 (Fos/Jun) functions in inflammatory bone and skin disease. Arthritis Res Ther. 2008;10(1):201.

61. Oeckinghaus A, Hayden MS, Ghosh S. Crosstalk in NF-kappaB signaling pathways. Nat Immunol. 2011;12(8):695-708.

62. Karin M. The regulation of AP-1 activity by mitogen-activated protein kinases. Philos Trans R Soc Lond B Biol Sci. 1996;351(1336):127-134.

63. Watanabe S, Kumazawa Y, Inoue J. Liposomal lipopolysaccharide initiates TRIF-dependent signaling pathway independent of CD14. PLoS One. 2013;8(4):e60078.

64. Roy S, Karmakar M, Pearlman E. CD14 mediates toll-like receptor 4 (TLR4) endocytosis and spleen tyrosine kinase (Syk) and interferon regulatory transcription factor 3 (IRF3) activation in epithelial cells and impairs neutrophil infiltration and Pseudomonas aeruginosa killing in vivo. J Biol Chem. 2014;289(2):1174-1182.

65. Takeuchi O, Akira S. Innate immunity to virus infection. Immunol Rev. 2009;227(1):75-86.

66. Bousquet J, Chanez P, Lacoste JY, et al. Eosinophilic inflammation in asthma. N Engl J Med. 1990;323(15):1033-1039. 


\section{Supplementary materials}

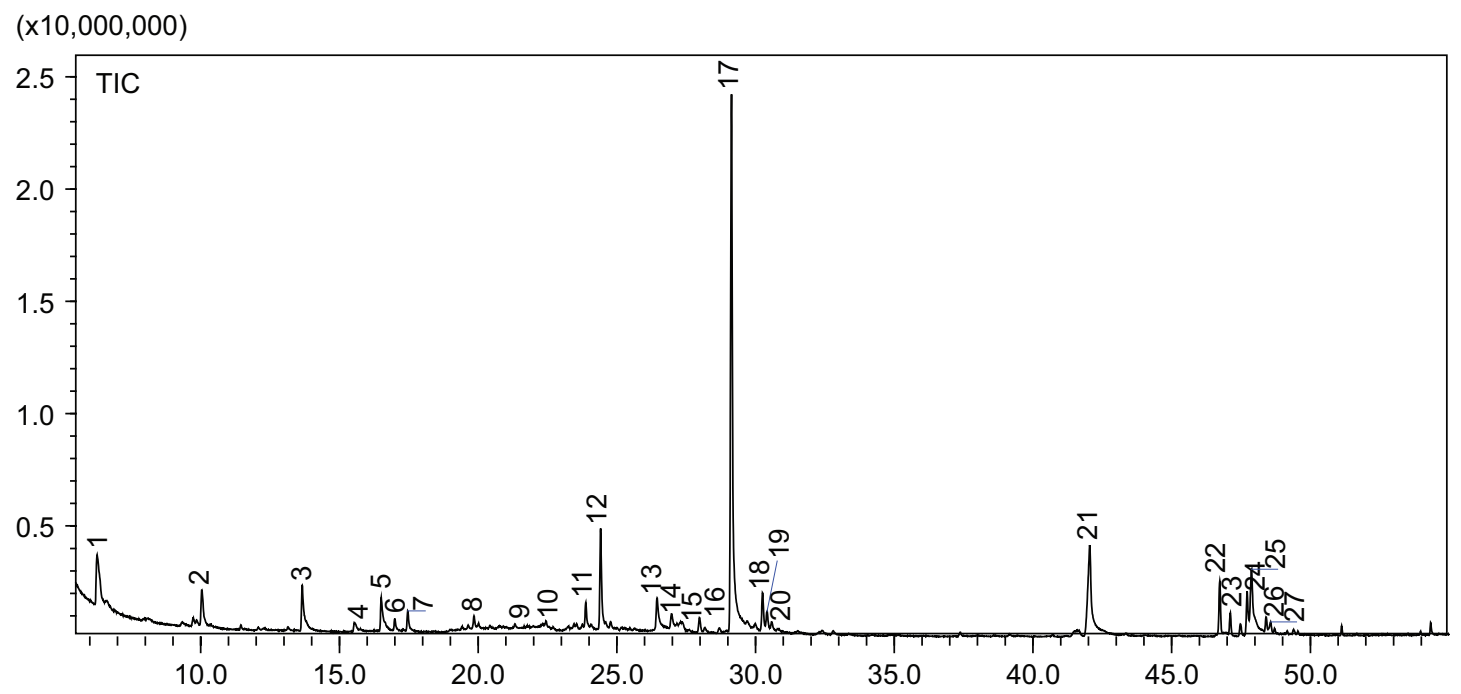

Figure SI GC chromatogram of DCEO.

Notes: DCEO was analyzed by GC-MS. Peak information is shown in Table SI.

Abbreviations: GC, gas chromatography; DCEO, Dingchuan tang essential oil; GC-MS, gas chromatography-mass spectrometry; TIC, total ion chromatogram.

Table SI Percentual chemical composition of DCEO

\begin{tabular}{|c|c|c|c|c|}
\hline $\begin{array}{l}\text { Peak } \\
\text { no }\end{array}$ & $\begin{array}{l}\text { Retention } \\
\text { time (min) }\end{array}$ & Compounds & $\begin{array}{l}\text { Molecular } \\
\text { formula }\end{array}$ & $\begin{array}{l}\text { Relative } \\
\text { contents (\%) }\end{array}$ \\
\hline 22 & 46.735 & D-Glucitol, hexaacetate & $\mathrm{C}_{18} \mathrm{H}_{26} \mathrm{O}_{12}$ & 2.29 \\
\hline 23 & 47.114 & Galactitol, hexaacetate & $\mathrm{C}_{18} \mathrm{H}_{26} \mathrm{O}_{12}$ & 0.88 \\
\hline 27 & 48.566 & (E)-9-Octadecenoic acid, ethyl ester & $\mathrm{C}_{20} \mathrm{H}_{38} \mathrm{O}_{2}$ & 0.91 \\
\hline 26 & 48.403 & 9,12-Octadecadienoic acid & $\mathrm{C}_{20} \mathrm{H}_{36} \mathrm{O}_{2}$ & 0.97 \\
\hline 25 & 47.88 & Oleic acid & $\mathrm{C}_{18} \mathrm{H}_{34} \mathrm{O}_{2}$ & 6.20 \\
\hline 24 & 47.719 & 9,12-Octadecadienoic acid (Z,Z)- & $\mathrm{C}_{18} \mathrm{H}_{32} \mathrm{O}_{2}^{2}$ & 2.07 \\
\hline 16 & 27.979 & Acetic acid, 6,6-dimethyl-2-methylene-7-(3-oxobutylidene)oxepan-3-ylmethyl ester & $\mathrm{C}_{16} \mathrm{H}_{24} \mathrm{O}_{4}$ & 0.72 \\
\hline 19 & 30.415 & 9, I2,I5-Octadecatrien-I-ol, (Z,Z,Z)- & $\mathrm{C}_{18} \mathrm{H}_{32} \mathrm{O}$ & 1.05 \\
\hline 14 & 26.973 & Acetate, 2-cyclohexenyl-3-[I-(2-oxopropyl)ethenyl]-2,4,4-trimethyl & $\mathrm{C}_{16} \mathrm{H}_{24} \mathrm{O}_{3}$ & 1.34 \\
\hline 21 & 42.044 & $n$-Hexadecanoic acid & $\mathrm{C}_{16} \mathrm{H}_{32} \mathrm{O}_{2}$ & 9.21 \\
\hline 18 & 30.252 & I,E-I I,Z-I3-Heptadecatriene & $\mathrm{C}_{18} \mathrm{H}_{32}$ & 1.79 \\
\hline II & 23.881 & E-I4-Hexadecenal & $\mathrm{C}_{16} \mathrm{H}_{30} \mathrm{O}$ & 1.34 \\
\hline 15 & 27.342 & Diethyl phthalate & $\mathrm{C}_{12} \mathrm{H}_{14} \mathrm{O}_{4}$ & 1.19 \\
\hline 20 & 30.578 & E-7-Tetradecen-I-ol & $\mathrm{C}_{14} \mathrm{H}_{28} \mathrm{O}$ & 0.60 \\
\hline 8 & $19.85 \mid$ & Copaene & $\mathrm{C}_{15} \mathrm{H}_{24}$ & 0.98 \\
\hline 9 & 21.327 & Caryophyllene & $\mathrm{C}_{15} \mathrm{H}_{24}$ & 0.63 \\
\hline 10 & 22.445 & I,6,I0-Dodecatriene, 7,I I-dimethyl-3-methylene-, (E)- & $\mathrm{C}_{15} \mathrm{H}_{24}$ & 0.57 \\
\hline 12 & 24.415 & $\beta$-Bisabolene & $\mathrm{C}_{15} \mathrm{H}_{24}$ & 4.71 \\
\hline 7 & 17.462 & Cyclohexanol, 2-methylene-3-(I-methylethenyl)- & $\mathrm{C}_{12} \mathrm{H}_{18} \mathrm{O}_{2}$ & 0.86 \\
\hline 17 & 29.132 & 4-(2,6,6-Trimethylcyclohexa-I,3-dienyl)but-3-en-2-one Dehydro- $\beta$-ionone & $\mathrm{C}_{13} \mathrm{H}_{18} \mathrm{O}$ & 28.43 \\
\hline 6 & 16.995 & I-Tridecene & $\mathrm{C}_{13} \mathrm{H}_{26}$ & 0.58 \\
\hline 4 & 15.537 & 2-Hexanoylfuran & $\mathrm{C}_{10} \mathrm{H}_{14} \mathrm{O}_{2}$ & 0.68 \\
\hline 13 & 26.453 & 7-Oxatetracyclo[4.2.0.0(2,4).0(3,5)]octane, 8-acetyl-8-methyl- & $\mathrm{C}_{10} \mathrm{H}_{12} \mathrm{O}_{2}$ & 2.27 \\
\hline 2 & 10.039 & I-Undecene & $\mathrm{C}_{11} \mathrm{H}_{22}$ & 2.24 \\
\hline 3 & 13.656 & p-Menth-I-en-8-ol & $\mathrm{C}_{10} \mathrm{H}_{18} \mathrm{O}$ & 2.96 \\
\hline 5 & 16.506 & Cycloundecene(E) & $\mathrm{C}_{11} \mathrm{H}_{20}$ & 2.36 \\
\hline I & 6.264 & Benzaldehyde & $\mathrm{C}_{7} \mathrm{H}_{6} \mathrm{O}$ & 4.37 \\
\hline Total & & & & 82.2 \\
\hline
\end{tabular}

Notes: A total of 27 components were characterized on the basis of a typical library research and literature data. The components showing matches exceeding $80 \%$, which represented $\sim 82.2 \%$ of DCEO, were selected.

Abbreviation: DCEO, Dingchuan tang essential oil. 


\section{Publish your work in this journal}

Drug Design, Development and Therapy is an international, peerreviewed open-access journal that spans the spectrum of drug design and development through to clinical applications. Clinical outcomes, patient safety, and programs for the development and effective, safe, and sustained use of medicines are the features of the journal, which

has also been accepted for indexing on PubMed Central. The manuscript management system is completely online and includes a very quick and fair peer-review system, which is all easy to use. Visit http://www.dovepress.com/testimonials.php to read real quotes from published authors.

Submit your manuscript here: http://www.dovepress.com/drug-design-development-and-therapy-journal 